\title{
Karadeniz Ekonomik İşbirliği Örgütü (KEİ) Örneğinde Bölgesel İşbirliği Örgütlerinin Etkileri ve Akdeniz Üzerine Değerlendirme ${ }^{1}$
}

\author{
Selahaddin BAKAN
}

Prof. Dr., İnönü Üniversitesi, İktisadi ve İdari Bilimler Fakültesi, Siyaset Bilimi ve Kamu Yönetimi Bölümü selahaddin.bakan@inonu.edu.tr Orcid ID: https://orcid.org/0000-0002-2444-7929

\section{Mehmet Emin GÜVEN}

Arş. Gör., İnönü Üniversitesi, İktisadi ve İdari Bilimler Fakültesi, Siyaset Bilimi ve Kamu Yönetimi Bölümü mehmetemin.guven@inonu.edu.tr Orcid ID: https://orcid.org/0000-0001-9863-5212

Öz

Ekonomik işbirliği örgütlerinin, üye ülkelerine sağladığı siyasi, ekonomik, sosyal ve kültürel işbirliği alanlarının üye ülkeler arasındaki ilişkileri desteklemeye ve sürdürmeye yönelik katkıları, bölgesel ve küresel çapta önemli etkiler yaratmakta ve olumlu sonuçlar ortaya çıkarmaktadır. Bu bağlamda bu çalışmada, Türkiye'nin girişimleri sonucu kurulan Karadeniz Ekonomik İşbirliği Örgütü'nün kuruluşu, amaçları ve hedefleri göz önünde bulundurulmuştur. Ülkelerin örgüte üyelik durumlarının, üye ülkeler arasındaki ekonomik, siyasi ve sosyal ilişkiler üzerine olan etkileri ve örgütün bölgesel sorunların çözümüne yönelik yaptığı katkılar değerlendirilmeye çalışılmıştır. Ayrıca çalışmada, Türkiye'nin gerçekleştirilmesinde aktif rol üstlenerek katkıda bulunabileceği ve Akdeniz'e kıyısı olan ülkelerle oluşturulacak bir Akdeniz işbirliği örgütünün, yakın dönemde yaşanan gelişmelerle birlikte bölgesel ve küresel aktörlerin doğrudan hedefi haline gelen, Akdeniz Havzası'nda bölge ülkelerinin ilişkileri üzerinde meydana getireceği düzenleyici etkiler ve bölgesel sorunların çözümüne ilişkin sağlayacağı katkılar değerlendirilmeye çalışılmıştır.

\footnotetext{
${ }^{1}$ Makale Geliş/Kabul Tarihi: 04.12.2020 / 13.03.2021

Künye Bilgisi: Bakan, S. ve Güven, M. E. (2021). Karadeniz Ekonomik İşbirliği Örgütü (KEI) örneğinde bölgesel işbirliği örgütlerinin etkileri ve Akdeniz üzerine değerlendirme. Kahramanmaraş Sütçü Imam Üniversitesi Sosyal Bilimler Dergisi, 18(1), 528-557. DOI: 10.33437/ksusbd.835867
} 
S.Bakan-M.E. Güven $\quad$ Karadeniz Ekonomik İsbirliği Örgütü (KEİ)...

Anahtar Kelimeler: Karadeniz Ekonomik İşbirliği Örgütü (KEİ), Bölgesel İşbirlikleri, Karadeniz, Akdeniz.

\title{
The Effects of Regional Cooperation Organizations in the Case of Black Sea Economic Cooperation (BSEC) and an Evaluation on the Mediterranean
}

\begin{abstract}
Economic Cooperation Organization member states that provide political, economic, social and cultural cooperation relations between member states and to continue to support the contribution, creating positive results and produces important effects on regional and global scale. In this context, in this study, Black Sea Economic Cooperation Organization's -established as a result of Turkey's initiatives- goals and aims are taken into consideration. The effects of the membership status of the states to the organization on the economic, political and social relations between the member states and the contributions of the organization to the solution of regional problems were tried to be evaluated. Also in the study, contribute by taking an active role in the realization of Turkey and the southern Mediterranean states to be created with a Mediterranean cooperation for the organization, together with the recent developments, regional and global actors in the Mediterranean basin, which has become the direct target of the regulatory effects on the relations of the regional states will bring and we tried to evaluate the contributions that would provide for the solution of regional problems.
\end{abstract}

Keywords: The Black Sea Economic Cooperation (BSEC), Regional Cooperation, Black Sea, Mediterranean

\section{GİRIŞ}

Bölgesel işbirliklerinin uluslararası ilişkileri düzenleyici etkileri yadsınamaz bir gerçeklik olarak önümüzde durmaktadır. Ekonomi temelli olarak gerçekleştirilen bölgesel işbirlikleri, üye ülkelerin karşılıklı olarak ticari ilişkilerine katkı sağlarken aynı zamanda üye ülkelerin siyasi, sosyal ve güvenlik, ilişkileri üzerinde şekillendirici bir etkiye sahiptir. Bölgesel işbirliklerinin sağladığ 1 avantajlar açısından; meydana getirilen işbirliği bölgelerinin oluşturduğu barış ve güven ortamının, oluşabilecek çatışma ve gerilim alanlarını azaltması ve olası tehlikeleri asgari düzeye indirmesi konusunda önemli etkileri olduğu düşünülmektedir. Bu bakımdan bölgesel işbirlikleri; bölge/üye ülkeler arasında yaşanacak olası siyasi, ekonomik ve sosyal sorunları önleyici bir etki alanı oluşturması, ülkelerin mevcut sorunlarını aşabilmesi açısından yeni firsatlar 
sunması ve bölgenin siyasi ve ekonomik huzuruna olumlu katkılar sağlaması noktasında önemli kazanımlar oluşturmaktadır.

Karadeniz Ekonomik İşbirliği Örgütü, kurulduğu 1992 y1lından itibaren coğrafi yakınlıkların belirdiği bir bölgesel ekonomik işbirliği örgütü olarak görev yapmaktadır. Coğrafi bakımdan Karadeniz'e kıyısı olan ülkeler arasında kurulmuş olan örgüt, Soğuk Savaş sonrası dönemde -özellikle Sovyetler Birliği’nin dağılmasından sonra- bağımsızlıklarını yeni elde eden bölge ülkeleri arasında ortaya çıkabilecek bölgesel nitelikli sorunları önleme amacını da taşımıştır. Bölge ülkeleri arasında kurulacak bir ekonomik birliktelikle bu amacın gerçekleştirilmesi hedeflenmiştir. Ekonomi temelli birlikteliklerin ülkeler arası sorunların çözümünde etkili olmasının ve bölgesel huzur ve refahın gelişimine katk1 sağlamasının örneklerini, bölgesel veya küresel olarak faaliyet gösteren yapılanmalarda görmek mümkündür. Örnek olarak ise büyük ölçekli bir ekonomik ve siyasi örgütlenme yapısına sahip olan Avrupa Birliği (AB) ve dünya çapında ekonomik ve siyasi saiklerle kurulmuş olan birçok farklı işbirliği örgütü gösterilebilir.

$\mathrm{Bu}$ çalışmada, Karadeniz Ekonomik İşbirliği Örgütü (KEİ) kapsamında örgütün, üye devletleri arasındaki ilişkilere etkisi ve bölgesel refah ve huzura olan katkısı değerlendirilmeye çalışılmıştır. Ayrıca bölgesel işbirliği örgütlerinin üye ülkeler arasındaki ilişkilere katkıları göz önünde bulundurularak, KEİ benzeri bir bölgesel ekonomik işbirliği örgütünün Akdeniz coğrafyasındaki varlığının; son zamanlarda Akdeniz'de -özellikle Doğu Akdeniz- yaşanan bölgesel sorunların önlenmesine yönelik bir çözüm aracı olmasının, aynı zamanda bölge ülkelerinin ekonomik, sosyal ve siyasi işbirlikleri oluşturmasının ve ülkelerin ilişkilerinin geliştirilmesine yönelik sağlayabileceği katkılar ele alınarak değerlendirilmeye çalışılmıştır.

\section{BÖLGESEL İŞBİRLİĞİ ÖRGÜTLERİ}

Bölgesel işbirlikleri ülkelerin; siyasi, ekonomik, askeri, sosyal ve kültürel alanlarda kalkınmak, iyi ilişkiler geliştirmek ve küreselleşmenin de yarattı̆̆ 1 imkanlardan faydalanarak küresel çapta etkinlik sahalarını artırmak ve genişletmek amacıyla kurmuş oldukları yapılanmalar olarak değerlendirilebilir. Bu bakımdan bölgesel işbirliği yapılanmalarının, küreselleşme ve bölgeselleşme olgularıyla yakın ilişki içerisinde olduğu söylenebilir.

Soğuk Savaş'ın sona ermesiyle birlikte dünya düzeninin iki kutuplu dünyadan tek kutuplu dünyaya evirilmesi, küreselleşmeyle beraber bölgeselleşme hareketlerini de meydana getirmiştir. Küreselleşme ve bölgeselleşme olgularını birbirlerine karşı zıt durumlar olarak gören yaklaşımlar olduğu gibi aynı zamanda bölgeselleşmenin küreselleşmeyle aynı doğrultuda olduğunu ve bir uluslararası ilişkiler şekli olduğunu iddia eden yaklaşımlar da mevcuttur (Karagül, 2014: 13). 
S.Bakan-M.E. Güven Karadeniz Ekonomik İsbirliği Örgütü (KEİ)...

Ancak küreselleşme ve bölgeselleşme arasındaki ilişkiye bakıldığı zaman iki yaklaşımında doğruluk paylarının olduğu görülmektedir. Küreselleşme ve bölgeselleşme arasındaki ilişki aslında bu iki olgunun karşılıklı olarak birbirini besleyen süreçler olduğunu ortaya koymaktadır.

Küreselleşme süreci, meydana getirdiği değişim ve dönüşümlerle ulus devletlerin tek başlarına üstesinden gelemeyeceği siyasal, sosyal, ekonomik ve çevresel birçok yeni sorun ortaya çıkarmıştır. $\mathrm{Bu}$ sorunların çözüme kavuşturulması amac1, dünya genelinde birçok alanda uluslararası örgütlenmelerin ortaya çıkmasını, süreklilik kazanmasını ve güçlenmesini gerekli kılmıştır (Bakan ve Tuncel, 2012: 60). Bu durum bazı alanlarda küreselleşmenin devam etmesini sağlarken bazı alanlarda ise bölgeselleşme hareketlerini hızlandırmıştır. Aslında küreselleşme ve bölgeselleşme arasında karşıtlık ilişkisi var gibi görülse de bölgesel işbirliği hareketleriyle ekonomik ilişkilerin artması sonucu küreselleşme süreci doğal olarak gerçekleşmektedir (Karluk, 1995: 2). Bu açıdan küreselleşme sürecinin meydana getirdiği olumsuz etkilerin, ülkelerin oluşturdukları bölgeselleşme hareketleriyle bir taraftan kırılmaya ve aşılmaya çalış1ldığ 1 , diğer taraftan ise bu durumun küreselleşme sürecine katkıda bulunarak küreselleşmeye hız kazandırdığı söylenebilir.

Ülkeler tarafından meydana getirilen işbirliği örgütleri, küreselleşmenin de etkisiyle, iletişim ve ulaşımda yaşanan değişimlerle birlikte ülkelerin karşılıklı bağımlılık unsurlarının, dolayısıyla bağımlılık ilişkilerinin, çoğalmasına katkı sağlamış ve uluslararası ilişkilerin şekillenişini önemli derecede etkilemiştir. Uluslararası ilişki düzeyinin yükselmesi ise ülkelerin karşılıklı faaliyet alanlarının çeşitlenmesini ve genişlemesini sağlamıştır. Bu durumun bölgesel işbirliği örgütlerine hem bölgesel hem de küresel açıdan -niteliksel değişiklikler göstermesi bakımından gelişimlerine ve niceliksel olarak ise sayılarındaki artışaolumlu yansımaları olmuştur.

İkinci Dünya Savaşı sonrası, küreselleşmenin etkileriyle birlikte ülkelerin birbirleriyle olan ilişkilerinde bağımlılıklarının artmaya başladığı ve dünya genelinde ülkelerin bölgesel entegrasyon denemeleri yaptıkları görülmektedir. Küreselleşmeyle birlikte sınırların önemini ve etkisini yitirmeye başlaması, sorunların da tek bir ülkenin sorunu olamayacağını ve çözümünün de yine tek bir ülke tarafından gerçekleşemeyeceği gerçeğini ortaya koymaktadır. Bu durum, ülkelerin birbirleriyle daha yakın ilişkiler geliştirebilecekleri ve işbirliği ve dayanışma alanlarını artırabilecekleri oluşumları, ekonomik birliktelikleri meydana getirmesinde etkili olmuştur (Şengül, 2009: 22).

İkinci Dünya Savaşı sonrası dönemde bölgeselleşme hareketlerinin iki farklı dalga halinde meydana geldiğine ilişkin görüşler bulunmaktadır. İlk bölgeselleşme dalgası olarak adlandırılan dönem, İkinci Dünya Savaşı sonrası 
1950'lerden 1970'li yılların sonuna kadar dünya ekonomisinde yer almıştır. Bölgesel oluşumların ikinci dalgası ise 1980'li yıllarda oluşmaya başlamış ve 1990'lı yıllardan itibaren ise etkisi artarak devam etmiştir (Özer, 2005: 25). Bu bakımdan yeni bağımsızlığını elde etmiş devletlerin, bölgesel işbirlikleri ve girişim alanlarını, kendi kalkınmalarını teşvik edecek ve yoğunlaşan uluslararası rekabet ortamında kendilerine bir koruma alanı sağlayacak olan bir araç olarak gördükleri düşünülebilir (Heywood, 2014: 572).

Bağımsızlığını yeni elde etmiş devletlerin ve gelişmekte olan ülkelerin bölgesel işbirliklerine yönelik bu yaklaşımlarının altındaki amaçlarının ise düşük ekonomik performansları nedeniyle sanayileşmiş ülkelere olan ekonomik ve siyasi bağımsızlıklarını azaltmak olduğu söylenebilir. Bu bağlamda, bu ülkelerin ekonomik dezavantajlı durumlarını bölgesel bloklar aracılığıyla giderebilme düşüncesiyle hareket ettikleri ifade edilebilir. Bölgesel işbirliği yapılanmaları, üye devletlerinin üye olmayan devletlerle ilişkilerini sınırlayıcı, dışlayıcı bir üyelik sistemine sahip değildirler. Böylelikle bölgesel işbirliklerinin, yeni katılımlara ve yeni üyeliklere olanak sağladığ 1 ve aynı zamanda üyelerinin de başka bölgesel işbirliklerine katılımlarına serbestlik tanıdığ 1 görülmektedir (Özer, 2005: 29-30).

Bölgesel işbirliğine dayalı olarak kurulan uluslararası örgütlerin hedeflerine bakıldığı zaman ilk hedefleri; bölge içerisinde, ülkeler arasında işbirliğinin sağlanmasıyla beraber siyasi, ekonomik ve sosyal bir sinerji alanı oluşturmak ve diğer bölgesel ve küresel güçler karşısında rekabet ederek durabilecek güçlü bir yapılanma oluşturabilmektedir. İkinci hedeflerinin ise, bölgesel işbirliği örgütleriyle birlikte oluşturulacak yeni güç merkezleri aracılığıyla işbirliğine dahil olan ülkelerin küresel sistem üzerindeki çıkarlarını koruma ve devam ettirebilme alanları oluşturabilmek olduğu görülmektedir (Karagül, 2014: 13). Küreselleşmeyle beraber hızla genişleyen küresel sermaye akışları ve ulus ötesi üretim modellerine yönelik eğilimin artması, bağımsız ekonomik birimler olan devletleri sıkıntıya düşürmüş ve bu nedenle de bölgesel oluşumları ülkeler için daha cazip hale getirmiştir (Heywood, 2014: 574). Entegrasyon hareketleri, bölgesel işbirlikleri ve çok uluslu şirketler küreselleşmeyi kısmen de olsa frenlemektedir ancak diğer taraftan küreselleşmenin de ayakta kalmasını sağlamaktadır (Bakan, 2019: 28-29). Bu bakımdan, küreselleşmenin yarattı̆̆1 etkilere karşı oluşturulan bölgeselleşme hareketlerinin aynı zamanda küreselleşmeyi yeniden üretmeye yönelik sonuçlar doğurduğunu da belirtmek gereklidir.

Küreselleşme, ülkelerin ekonomilerinin dünya piyasalarıyla bütünleştirilmesi ve tüm ekonomik kararların sermaye birikimine ilişkin değişkenlere göre alınmas1 olarak değerlendirilebilir (Aslan, 2005: 6). Bu bakımdan küreselleşmenin, artan ekonomik bağımlılığı da ifade ettiği söylenebilir. 
S.Bakan-M.E. Güven Karadeniz Ekonomik İsbirliği Örgütü (KEİ)...

Bölgeselleşme ise genel anlamda coğrafi bir içeriğe sahip olsa da ülkelerin ekonomik, sosyal veya siyasi işbirliğinin sağlanması yoluyla firsatlar yaratmasını amaçlamaktadır. Bölgesel işbirliklerinin ise temelde ekonomik olmak üzere siyasi ve sosyal entegrasyonun sağlamasına yönelik girişimlerin sonucu olarak ortaya çıtığı söylenebilir.

Küreselleşmeyle birlikte artan bağımlılık ilişkileri, ülkeleri özellikle ekonomik entegrasyona yönelik işbirliğini gerçekleştirmeye yönelik bölgesel oluşumlar kurmaya yöneltmiştir. Ekonomik entegrasyon ise siyasi açıdan bağımsız olan devletleri ekonomik açıdan birbirlerine bağımlı hale getirmiştir (Şanl1, 2008: 14). Bölgesel işbirliklerinin oluşturduğu bağımlılık ilişkisi, üye devletler arasındaki ilişkinin ortaya çıkardığı katkı, bölgesel yararın toplamını oluşturmaktadır ve oluşan toplam fayda ise birliğe ve birliğe üye ülkelere fayda sağlamaktadır.

1989 yılında Berlin Duvarı'nın ve ardından 1991 yılında Sovyetler Birliği'nin yıkılmasıyla birlikte Soğuk Savaş döneminin sona ermesi, iki kutuplu dünya düzeni dönemini sonlandırmıştır. Blok yaklaşımı anlayışının bitişiyle birlikte küreselleşmenin de etkisiyle dünyada hızlı değişimler ve dönüşümler yaşanmaya başlamış, bloksuzluk/kutupsuzluk ${ }^{2}$ anlayışı veya dönemi ön plana çıkmıştır. $\mathrm{Bu}$ açıdan AB, BM, IMF, OPEC, AGİT, KEİ, Dünya Bankası, Şangay İ̧̧birliği, Arap Birliği, İslam İşbirliği Örgütü gibi birçok uluslararası örgüt ve çok uluslu şirket mevcut sistemin bloksuz/kutupsuz olarak nitelendirilmesinde etkili olmuştur. $\mathrm{Bu}$ oluşan bloksuz yeni uluslararası sistem ise 'Yeni Dünya Düzeni' olarak adlandırılmıştır (Arı, 2013: 171-174).

Karadeniz Ekonomik İşbirliği Örgütü'nün (KEI), dünyada yaşanan küreselleşme sürecinin etkileri içinde bölgesel düzeyde kurulmuş olduğu ve uluslararası bütünleşme yönünde ekonomik ve siyasi alanda yeniden yapılanma sürecinin bir ürünü olduğu söylenebilir (Özgöker ve Bat1, 2017: 165).

\section{Karadeniz Ekonomik İşbirliği Örgütü (KEI)}

Karadeniz Ekonomik İşbirliği Örgütü, Türkiye'nin öncülüğünde başlatılan girişimler sonucu 1992 yılında kurulmuş ekonomik temelli bölgesel nitelikli bir devletlerarası bölgesel işbirliği örgütüdür. Karadeniz Ekonomik İşbirliği Örgütü, üye ülkelerinin coğrafi sınırlarıyla birlikte yaklaşık 19,5 milyon $\mathrm{km}^{2}$ ’lik toprak alanı ve sahip olduğu yaklaşı 350 milyon insan nüfusuyla önemli bir bölgeyi kapsamaktadır. Ayrıca KEİ üye ülkelerinin bulundukları coğrafi konumları

${ }^{2}$ Bloksuzluk veya kutupsuzluk kavramı ilk defa Richard Haas tarafindan kullanılmıştır. Kavram, yeni uluslararası sistemde bağımsız hareket etme kapasitesine sahip güçlerin var olduğunu, artık ülkelerin belli başı ülkelerin etrafında toplanarak bloklar oluşturmadığını ifade etmektedir. 
itibariyle önemli jeostratejik alanlara hâkim olması, önemli doğalgaz ve petrol rezervlerine sahip olması ve doğu-batı arasında önemli geçiş güzergahları -enerji nakil yollar1- üzerinde bulunması, KEİ'nin önemini ve gerekliliğini de ortaya koymaktadır.

Karadeniz Ekonomik İşbirliği Örgütü’nün (KEİ) fikir babası olarak emekli büyükelçi Şükrü Elekdağ gösterilebilir. Elekdağ, 1989 yılında yazdığı köşe yazılarında Türkiye'nin Ortadoğulu ve Avrupalı olduğu kadar aynı zamanda Asyal1, Kafkasyalı, Karadenizli ve Akdenizli bir ülke olduğunu belirtmiş ve gerçekleştirilebilecek bölgesel işbirliklerinin Türkiye'ye yeni olanaklar sağlayacağını öne sürmüştür. Soğuk Savaş sonrası oluşan şartların jeopolitiği ise Karadeniz'de böylesi bir işbirliğini geliştirebilme imkânı sunmuştur (Altıntaş, 2006: 640-641). Nitekim Elekdağ' In önerisini Karadeniz Ekonomik İşbirliğgi projesi olarak hayata geçiren ise Türkiye'de 1980'den itibaren uygulanmaya başlayan liberal ekonomi politikaların da öncüsü olan 8. Cumhurbaşkanı Turgut Özal olmuştur (Çağıran, 2000: 6).

Karadeniz Ekonomik İşbirliği Örgütü’nün (KEİ) kurulması düşüncesinin altında, 1980'li yıllarda Sovyetler Birliği'nin temel gıda ve ana tüketim mallarına olan ihtiyacının ve Türkiye'nin de enerjiye olan ihtiyacının karşıllklı olarak işbirliği çerçevesinde karşılanması fikri yatmaktadır. Bu fikir, daha sonra Bulgaristan ve Romanya'nın da katılmasılyla birlikte bölgesel işbirliği zemininde şekillenmeye ve olgunlaşmaya başlamıştır (T.C. Dışişleri Bakanlığı, 2020).

Enerji kaynakları ve hammadde yönünden zengin rezervlere sahip olan Sovyetler Birliği, harcamalarını daha çok savunma ve uzay sanayii alanlarına yönelik yaparken, temel gıda ve tüketim malları başta olmak üzere insani yatırımlara aynı düzeyde hassasiyet göstermemiştir. Türkiye ise Batı'ya pazarlamada güçlük çektiği ve Sovyetler Birliği'nin en çok ihtiyaç duyduğu alan olan temel gıda ve tüketim malları konusunda önemli bir avantaja sahiptir. $\mathrm{Bu}$ bakımdan hızlı bir sanayileşme dönemine giren Türkiye, Sovyetler Birliği’nin enerji kaynaklarına ve hammaddelerine ihtiyaç duyarken, Sovyetler Birliği ise Türkiye'nin üretiminde güçlü olduğu gıda ve tüketim mallarına ihtiyaç duymaktaydı. Ayrıca ilişkilerin geliştirilmesi bakımından Sovyetler Birliği'nde bulunan Türk Cumhuriyetleri'nin varlığı bu ilişkide olumlu bir etken olmuştur (Karagül, 2014: 145-146). Diğer taraftan bu dönemde Türkiye'de, dış politikada ekonomiyi önceleyen bir hükümetin başta olması ve dışa açık ekonomi politikalarının izlenmesi, Türkiye'nin böyle bir girişime öncülük edebilmesinde önemli katkılar sağlamıştır (Çağıran, 2000: 6). Bu bakımdan mevcut siyasi durumun, yaşanan gelişmelerin ve karşılıklı bağımlılık ilişkilerinin geliştirilmesinin, Türkiye ile Karadeniz'e kıyısı olan ülkeler arasında kurulacak olan ekonomi temelli bölgesel işbirliği ve bütünleşme alanı için uygun ortamı oluşturduğu söylenebilir. 
S.Bakan-M.E. Güven Karadeniz Ekonomik İsbirliği Örgütü (KEİ)...

Kuruluş aşamasında KEI'nin temel amacının, Karadeniz kıyılarına sınırı olan ülkeler arasında aşamalı olarak gerçekleşmesi planlanan bir serbest ticaret bölgesi oluşturma fikri olmuş olsa da ilerleyen süreçte ülkeler arasında gerçekleştirilen zirveler ve toplantılar sonrası örgütün ekonomik işbirliği kapsamında değerlendirilmesi kararlaştırılmıştır.

\section{KEI'nin Kuruluşu ve Amaçları}

Karadeniz Havzası'nda bulunan ülkeler arasında işbirliği arayışlarına yönelik ilk adımlar, 1990 yılının Ağustos ayında Türkiye Cumhuriyeti Dışişleri Bakanlığ 1 tarafından atılmıştır. Bu adımlar sonrası yapılan ön mutabakatlar çerçevesinde ülkeler arasında ilk toplantı, 19/21 Aralı 1990 tarihlerinde Ankara'da düzenlenmiştir. Toplantıya, Türkiye, Sovyetler Birliği, Bulgaristan ve Romanya delegelerinin yanı sıra, Sovyetler Birliği'nin heyeti içinde yer alan Azerbaycan, Moldova, Gürcistan ve Ermenistan dışişleri bakan yardımcıları katılmıştır. Toplantıda; Türkiye tarafından hazırlanan, işbirliği önerisini içeren ve temel prensipleri kapsayan taslak üzerinde çalışılmış, sonuç bildirisinde ise Karadeniz Ekonomik İşbirliği'nin (The Black Sea Economic Cooperation-BSEC) kurulması yönünde anlaşmaya varılmıştır (Altıntaş, 2006: 641). Bu toplantıyı sırasıyla 12/23 Mart 1991 tarihleri arasında Bükreş’te, 23/24 Nisan 1991 tarihleri arasında Sofya'da ve 11/12 Temmuz 1991 tarihleri arasında Moskova'da düzenlenen toplantılar izlemiştir (Özgöker ve Bat1, 2017: 166).

Karadeniz Ekonomik İşbirliği, 25 Haziran 1992 tarihinde Türkiye’nin girişimleri sonucu toplanan ve İstanbul Zirvesi'nde yayımlanan deklarasyon ile kurulmuştur. Zirve toplantısına katılan ülkelerin devlet başkanları tarafindan deklarasyon imzalanmış ve resmen işlerlik kazandırılmıştır (Karluk, 1995: 387).

Karadeniz Ekonomik İşbirliği'nin diğer zirvesi ise 5 Haziran 1998'de Ukrayna'nın Yalta şehrinde düzenlenmiştir. Bu zirvede daha önceki zirvelerde ele alınan konular tekrar ele alınmış, kurumsal bir yapı kazandırılmak adına ilgili alt kurumlar ve birimlere havale edilmiştir. Daha öncesinde Moskova zirvesinde ele alınan ve Karadeniz Ekonomik İşbirliği'nin hukuki ve kurumsal yapısının güçlendirilmesi ve işbirliğinin artırılması için bir örgüte dönüştürülmesi fikri, bu zirvede karara bağlanmış ve resmen bölgesel bir örgüt (Karadeniz Ekonomik İşbirliği Örgütü) halini almıştır (Çağıran, 2000: 16-17). KEI'nin nihai olarak bir örgüt haline gelmesi; uluslararası platformlarda daha fazla tanınmasını, temsil imkânı bulmasını ve KEİ bünyesinde yürütülmesi planlanan projeler için gerekli yardımların ve desteklerin uluslararası mali kuruluşlardan sağlanmasını kolaylaştırması bakımından önem arz etmektedir (Altıntaş, 2006: 643).

Karadeniz Ekonomik İşbirliği Örgütü; Arnavutluk, Azerbaycan, Bulgaristan, Ermenistan, Gürcistan, Moldova, Romanya, Rusya Federasyonu, Sirbistan, Türkiye, Ukrayna ve Yunanistan olmak üzere üye konumunda bulunan devletler 
tarafından teşkil edilmektedir. 2004 yılında itibaren Sırbistan'ın katılımıyla birlikte örgütteki üye devlet sayısı 12'ye ulaşmıştır (T.C. Dışişleri Bakanlığı, 2020). KEİ'nin üyelerine bakıldığı zaman üye ülkelerin Karadeniz'e sınır veya Karadeniz Havzası'na yakın ülkeler tarafından oluşturulduğu görülmektedir. Ayrıca üye ülkeler arasında Türkiye ve Yunanistan dışındaki ülkelerin hepsinin eski Doğu Bloğu'nu oluşturan ülkeler tarafindan meydana getirildiği de görülmektedir (Çelik, 2005: 439).

Türkiye, Azerbaycan, Ermenistan, Gürcistan, Moldova, Rusya Federasyonu, Ukrayna, Bulgaristan ve Romanya kurucu üye ülkeler konumundaki ülkelerdir (BSEC, 2020). ABD, AB Komisyonu, Almanya, Avusturya, Çek Cumhuriyeti, Fransa, Hırvatistan, İsrail, Misır, Polonya, Slovakya ve Tunus ise gözlemci ülkeler konumundadırlar (Engin, 2016: 89).

KEİ, kurulduğu dönemde içinde bulunduğu konjonktürden dolayı ilk olarak siyasal yumuşamayı hedeflemiştir. Bu nedenledir ki; örgüt ilk maddesinde barış ve insan haklarına ilişkin vurgu yaparak bunun sağlanmasına yönelik bir ortam oluşturmayı hedeflemiş, Helsinki Nihai Senedi, Avrupa Güvenlik ve İşbirliği Konferansı (AGIK) ve Paris Şartı'na atıflarda bulunularak temel bir amaç belirlenmeye çalışılmıştır. İkinci maddesinde ise bu amaç, bireysel ve toplumsal alana indirilerek siyasi ve ekonomik refahın bütünleştirilmesi konuları odak noktası yapılmıştır. Üçüncü maddesinde coğrafi yakınlığın sağladığı avantajlara, dördüncü maddesinde ise, Karadeniz merkezli bir çevre politikasına dikkat çekilmiştir. Beşinci ve altıncı maddelerinde geniş bir ekonomik alanda ekonomik bütünleşmeyi hedefleyecek ve gerçekleştirecek amaçlar ele alınmıştır. Devam eden maddelerde ise iktisadi alana ve ilişkilere ağırlık verilmiştir (Ertürk, 1993: 241-242). Bu bakımdan, ortaya konan maddeler ve ilkeler açısından, KEİ'nin diğer benzer oluşumlara karşı meydana getirilmiş bir yapılanma olmadığ 1 görülmektedir. Aksine amacının Avrupa'daki gelişmelere benzer bir süreci kendisinin de gerçekleştirerek benzer bir uyumu yakalama çabası içinde olduğu söylenebilir (Çağıran, 2000: 7).

Karadeniz Ekonomik İşbirliği Örgütü’nün temel amaçlarına bakıldığı zaman;

- Üye ülkelerin birbirlerine olan coğrafi yakınlıkları göz önünde bulundurularak, üye ülkelerin ekonomilerinin birbirlerini tamamlayıcı özelliklerinden yararlanmasını sağlamak.

- Ekonomik, ticaret, bilimsel ve teknolojik işbirlikleri oluşturmak ve geliştirmek.

- Karadeniz Havzası'nda siyasi bir bütünleşmeden ziyade ülkeler arası dostluk ilişkilerinin geliştirilerek, Karadeniz'in bir barış ve refah bölgesi haline getirilmesini sağlamak. 
S.Bakan-M.E. Güven Karadeniz Ekonomik İsbirliği Örgütü (KEİ)...

- Kısa dönemde bölge ülkeleriyle uygun işbirliği ortamının kurulması ve mal ve hizmet ticaretinin geliştirilmesi.

- Uzun dönemde ise kişilerin, sermayenin, malların ve hizmetlerin serbest dolaşımının sağlanması,

olduğu söylenebilir. ${ }^{3}$

KEİ amaçları doğrultusunda ele alındığında dönemsel olarak kısa vadede; üye ülkelerin bölge ülkeleriyle olan ișbirliğinin sağlanması için uygun ortamın hazırlanmasını, üye ülkeler arasında mal ve hizmet ticaretinin geliştirilmesini ve sınır ve kıyı ticaretinin canlandırılmasını amaçlamaktadır. Bu amaçların gerçekleştirilmesine yönelik olarak gümrük ve vize kolaylıklarının sağlanması, ulaşım ve iletişim alanlarında işbirliklerinin oluşturulmasını hedeflemektedir. Uzun vadede ise, üye ülkeler arasında mevcut ekonomik ilişkilerin daha da geliştirilmesi amacıyla dört temel özgürlük kapsamında kişilerin, sermayenin, malların ve hizmetlerin serbest dolaşımının sağlanacağı serbest ticaret bölgesinin kurulmasını hedeflemektedir (Duran, 2004: 9). KEI'nin daha uzun dönemdeki hedeflerine bakıldığında ise bölgede Avrupa Birliği'ne (AB) benzer bir yapıyı tesis etmek olduğu söylenebilir (Karagül, 2014: 147). Bu doğrultuda KEİ'nin kuruluş amacının, üyesi olan bölge ülkeleri arasında ticaretin geliştirilmesi ve ekonominin canlandırılması olduğu ve üye ülkelerin refah düzeylerinin yükseltilmesine katkıda bulunurken aynı zamanda bölgenin de kalkınmasının sağlanması olduğu söylenebilir.

\section{KEI'nin Gelişimi}

Karadeniz Ekonomik İşbirliği Örgütü'nün gelişim sürecinde, örgütün kurumsallaşma süreçlerine katkıda bulunacak organlar kurulmuştur. $\mathrm{Bu}$ çerçevede üye ülkeler arasında ve diğer bölge ülkeleriyle ilişkilerin kurulması, sürdürülmesi ve geliştirilmesine yönelik olarak üye devletlerin hükümetlerini, iş ve finans çevrelerini içine alacak şekilde geniş bir organizasyon yapısı oluşturulmuştur. Yapıyı meydana getiren organlar, örgüt içi ilişkilerin düzenlenmesinde ve işlerin yürütülmesinde etkili mekanizmalar olarak görev yaparken, aynı zamanda örgütün organizasyon niteliği kazanmasında ve kurumsal yapısının şekillenmesinde etkili olmaktadır.

1998 yılında toplanan zirve sonrası örgüt niteliği kazanan KEİ'nin yapısında daha öncesinde faaliyetlerine devam eden birçok organ bulunmaktadır. $\mathrm{Bu}$

${ }^{3}$ Detaylı bilgi için bkz., BSEC (2020), Organization of the Black Sea Economic Cooperation: http://www.bsec-organization.org/areas-of-cooperation

T.C. Dışişleri Bakanlığı (2020), T.C. Dışişleri Bakanlığı, Karadeniz Ekonomik İşbirliği

Örgütü (KEI): www.mfa.gov.tr/karadeniz-ekonomik-isbirligi-orgutu_kei_.tr.mfa 
bakımdan KEİ'nin kurumsallaşma sürecinin ilk adımları, işbirliği girişimlerinin başladığ İstanbul Zirvesi’ne kadar uzanmaktadır. 1992 yılında gerçekleştirilen İstanbul Zirvesi'nde, KEİ'nin başlangıçta kurumsal yapısının esnekliğine önem gösterilmiş ve bu nedenle de örgüt kelimesinden özellikle imtina edilmiştir. Bu düşünceyle, üye ülkelerin dışişleri bakanlarının katılımıyla oluşturulan ilk daimî organ "Dışişleri Bakanları Toplantısı" olarak isimlendirilmiştir. Daha sonra KEİ'nin örgüt statüsüne kavuşmasıyla birlikte "Dışişleri Bakanları Konseyi" adını almıştır (Çağıran, 2000: 17-18). Bununla birlikte üyelerin ortak kararlarıyla çalışacak olan ve uzmanlardan oluşan daimî ve geçici çalışma grupları oluşturulması kararları da alınmıştır (Karagül, 2014: 148).

Dışişleri Bakanları Konseyi/Toplantısı, örgütün en yüksek karar alma organıdır. Altı ayda bir olmak şartıyla yılda iki kez toplanmaktadır ve konseyin ilk iki dönem başkanlığını Türkiye yapmıştır. Daha sonraki başkanlık dönemlerinde ise alfabetik sıra takip edilmiştir. Dışişleri Bakanları Konseyi; KEİ'nin işleyişi, alt organların oluşturulması ve çalışmalarının yönlendirilmesi, alınan kararların değerlendirilmesi, gözlemci ülke statüsünün belirlenmesi ve iç tüzügün değiştirilmesi ve kabul edilmesi konularında yetkilidir (Özgöker ve Batı, 2017: 169). Dişişleri Bakanları Konseyi, KEİ bünyesinde sürdürülmekte olan faaliyetlerin değerlendirilmesi ve çalışma gruplarından alınan kararların onaylanması amaciyla ilk toplantısını 10/12 Aralık 1992 tarihinde Antalya'da düzenlemiştir. Bu toplantı sonrası "Uluslararası Daimî Sekretarya" kurulması kararlaştırılmıştır. Sekretaryanın kurulması, KEI'nin kalıcı bir nitelik kazanması bakımından önemli bir yere sahiptir (Karluk, 1995: 388).

1992 yılında İstanbul Zirvesi’nde gündeme gelen diğer organ ise "Karadeniz Ticaret ve Kalkınma Bankası"dır. Birçok alanda faaliyet sürdürmeyi amaçlayan KEİ, finansal alanda göstereceği faaliyet alanı için gerekli kurumsal alt yapıyı oluşturmuştur. Karadeniz Ticaret ve Kalkınma Bankası (KTKB), 30 Haziran 1994 tarihinde Tiflis'te yapılan KEİ Dışişleri Bakanları 4. Toplantısı'nda taraflarca imzalanmış, Türkiye tarafından 1996 tarihli kanunla onaylanarak kurulmuş ve bankanın genel merkezi Selanik şehrinde açılmıştır (Karagül, 2014: 149). Bankanın başkanlığını Türkiye, yardımcılığını ise Bulgaristan üstlenmiştir ve bu süreler 4 yıl ile sınırlandırılmıştır (Altıntaş, 2006: 650).

Bölgede yatırımları ve ticari faaliyetleri finanse edecek bir yapı olarak kurulan KTKB, kâr amacı gütmemekle birlikte ortak bölgesel projeleri destekleyerek üye devletlere gerekli parasal yardımlar yapmayı ve bölge ülkelerinin kalkınmalarını sağlamak için ucuz krediler tedarik etmeyi amaçlamaktadır. Bu bakımdan KTKB'nin üyeleri, KEI üye ülke temsilcileri, uluslararası finans ve banka kuruluşlarından oluşmaktadır (Özgöker ve Batı, 2017: 171). Yaklaşık 3,5 milyar Euro sermayesiyle Karadeniz Ticaret ve Kalkınma Bankası, üye ülkelerdeki hem kamu hem de özel işletmeleri destekleyen kalkınma projeleri için ticaret ve proje 
S.Bakan-M.E. Güven Karadeniz Ekonomik İsbirliği Örgütü (KEİ)...

finansmanlarını, garantiler ve eşitlikler sağlayarak ekonomik kalkınma ve bölgesel işbirliğini desteklemektedir (BSEC, 2020).

Karadeniz Ekonomik İşbirliği Örgütü’nün bir diğer önemli organı “Karadeniz Ekonomik İşbirliği Parlamenter Asamblesi” (KEIPA)'dir. 26 Şubat 1993 tarihinde Yunanistan ve Bulgaristan dışındaki ${ }^{4} \mathrm{KEİ} \mathrm{üyesi} \mathrm{ülkelerin} \mathrm{katılımlarıyla}$ oluşturulmuştur (Çağıran, 2000: 46). KEİ üyesi ülkelerin hükümet başkanları zirvelerinde ve Dışişleri Bakanları Konseyi'nde aldıkları kararların uygulanabilirliğini sağlayacak yasal düzenlemeleri yapmak, KEİ'nin amaç, hedef ve ülkülerinin üye devletlerin halklarına benimsetmek, parlamenter demokrasinin gelişimine katkıda bulunmak ve uluslararası kuruluşlarla KEI üyesi ülkeler arasındaki işbirliğinin ve ilişkilerin geliştirilmesi, KEİPA'nın amaçları arasında yer almaktadır (Alkan, 2006: 30).

KEİPA'nın aldığı kararların bağlayıcı yasama yetkisi bulunmamaktadır. Bu bakımdan yaptığı düzenlemeler tavsiye niteliğindedir (Şengül, 2009: 41). Genel Kurul ve Daimî Komite olmak üzere iki alt organı ve üç uzmanlık komisyonu bulunmaktadır. Genel Kurul, en yüksek karar alma organı olmakla birlikte yetmiş üyeden oluşmaktadır ve üye devletler nüfuslarına oranla temsilci bulundurmaktadırlar (Çelik, 2005: 441). Daimî Komite; parlamento kararlarını takip ederek toplantı ve gündemi belirlemekte, bütçeyi oluşturup fonları yönetmekte ve uluslararası kuruluşlarla işbirliğini sağlamaktadır (Sanalan, 1997: 150). Ayrıca Asamblenin; "Ekonomi, Ticaret, Teknoloji ve Çevre Komisyonu", "Hukuki ve Siyasi İşler Komisyonu" ve "Kültür, Eğitim ve Sosyal İşler Komisyonu" olmak üzere üç ayrı uzmanlık komisyonu bulunmaktadır (Altıntaş, 2006: 648).

Karadeniz Ekonomik İşbirliği Örgütü'nün diğer bir organı ise "Karadeniz Ekonomik İşbirliği Konseyi” (KEIK)'dir. 1992 y1lında kurulmuş olan KEİ Konseyi, 12 üye devletin iş çevrelerinin temsil edilmesini sağlayan ve geniş Karadeniz Havzası'nda ticari işbirliği ve bölgesel entegrasyonu teşvik etmeyi amaçlayan bir yapılanmadır. Özel sektörün ve yerel iş insanlarının yararının gözetilmesi, Karadeniz Havzası boyunca iş ortamının iyileştirilmesinin sağlanması, yabancı yatırımları çekmeye yardımcı olmak amacıyla kurulmuş bir organdır ve kâr amacı taşımamaktadır. KEİ Konseyi'nin merkezi uluslararası sekretaryası ise İstanbul'dadır (BSEC, 2020). KEİK, özel sektör unsurlarının çeşitli alanlardaki yatırım projelerini bir araya getirerek bu projelerin gerçekleştirilmesini sağlamak adına altyapının güçlendirilmesi için üye ülkelerin

\footnotetext{
${ }^{4}$ Karadeniz Ekonomik İşbirliği Asamblesi’ne, Yunanistan 1995 yılında Bulgaristan ise 1996 yılında katılmışlardır. Ayrıca KEIPA, üye olmayan diğer devletlere ve uluslararası kuruluşlara da gözlemci üye olma hakkı tanımaktadır.
} 
kamu kuruluşlarına gerekli desteğin sağlanmasında yardımcı olmaktadır (Özgöker ve Bat1, 2017: 171).

Bu kurumların yanında örgütün işleyişine, gelişimine ve sürekliliğine katkıda bulunan; 'Karadeniz İşbirliği Akademik Komitesi', 'Karadeniz Çalışmaları Uluslararası Merkezi', 'Küçük ve Orta Ölçekli İşletmeler Merkezi' ve 'İstatistik Veri ve Ekonomik Bilgi Değişim Eşgüdüm Merkezi' gibi diğer birimler de önemli yere sahiptir. Karadeniz Ekonomik İşbirliği Örgütü’nün kurumsal olarak yapılanması ve kurumsal yapılanmasını tamamlaması, örgütün daha etkili şekilde çalışmasını sağlayarak uluslararası arenada etkinliğini artırmasını ve kanıtlamasını sağlamıştır.

\section{KEI'NİN ÜLKELER ARASINDAKİ İLİŞKİLERE ETKİSİ}

Bölgesel işbirliği örgütleri, örgüte üye ülkelerin kendi aralarında ve üye ülkelerin üye olmayan diğer ülkelerle geliştirdikleri siyasi, ekonomik, sosyal ve kültürel ilişkiler üzerinde ülkelerin etkinlik düzeyleri açısından önemli etkilere sahiptir. Bu açıdan, Karadeniz Ekonomik İşbirliği Örgütü üye ülkelerinin birbirleriyle ve diğer ülkelerle olan ilişkilerinde, ülkelerin siyasi, ekonomik, sosyal ve kültürel yapılarının belirleyici etkileri bulunmaktadır. Bölgesel ekonomik işbirliklerinin ekonomik entegrasyon oluşturma başarısında örgüte üye ülkelerin; coğrafi yakınlık durumları, ekonomik sistem uyumluluğu ve ekonomik gelişmişlik düzeylerinin birbirlerine yakınlığı kadar üye ülkelerin siyasi, sosyal ve kültürel yapılarının birbirlerine benzerlikleri ve aşinalıkları da işbirliklerinin gelişiminde önemli yere sahiptir. Bu bakımdan bölgesel işbirlikleri kapsamında KEİ üyesi ülkelerin siyasi, sosyal ve kültürel ilişki durumları, üye ülkeler arasındaki mevcut ilişkilerin şekillenmesi ve örgütün başarısı üzerine önemli katkılar sağlamaktadır.

\section{Siyasi İlişkilere Etkisi}

Karadeniz Ekonomik İşbirliği Örgütü, her ne kadar temelde ekonomik bir birliktelik alanı oluşturma amacıyla kurulmuş olsa da üye ülkelerin kendi aralarında ve diğer ülkelerle geliştirdikleri ilişkilerin siyasi niteliği de önem arz etmektedir. Bu açıdan KEİ'nin iktisadi amaçları ve hedeflerine ek olarak üyelerini yakından ilgilendiren siyasi konuların da ele alındığı siyasal bir platforma sahip yönü bulunmaktadır.

Sovyetler Birliği dağılmadan önce Sovyetler bünyesinde bulunan devletler, sosyalist rejimle yönetilen siyasi ve iktisadi bir yapıya sahiptiler. Sovyetlerin dağılmasından sonra iki karşıt blok rekabeti üzerinden şekillenen dünya sisteminin çökmesi yerini daha homojen bir yapıya bırakmıştır. Sovyetler Birliği'ne bağlı olan bölge devletler, bağımsızlıklarını kazanmalarıla birlikte daha önceleri karşı mücadele yürüttükleri batı tipi siyasi ve iktisadi yönetim 
S.Bakan-M.E. Güven Karadeniz Ekonomik İsbirliği Örgütü (KEİ)...

anlayışına doğru siyasi ve iktisadi dönüşümler yaşamıştır (Çağıran, 2000: 5). Bu değişim ve dönüşümler, Karadeniz Havzası'nı yakından etkilemiştir. Bu bağlamda KEI'nin ortaya çıkışında, ABD ve Sovyetler Birliği'nin etkisi altında kalan Karadeniz Havzası ülkelerinin siyasi arayışlarının, ekonomik zeminde uygun ortam bulmalarının sonucu olduğu düşünülebilir. KEİ'nin, başlangıçta sadece 'serbest ticaret bölgesi' olarak kurulma amacı da bu düşünceyi destekler niteliktedir.

Siyaset ve ekonominin birbirleriyle olan yakın ilişkisi iki alanın da karşıllıklı olarak birbirlerini etkileme düzeyini artırmaktadır. Siyasetin ekonomiden bağımsız düşünülemeyeceği gerçeği aynı şekilde ekonominin de siyasetten bağımsız şekillenemeyeceği gerçeğini ortaya koymaktadır. KEİ her ne kadar da ekonomik işbirliği çerçevesinde bölgesel işbirliği örgütü olarak kurulmuş olsa da amaçlarına baktığımız zaman örgütün ilk amaçları arasında; üye ülkeler arasındaki dostluk ve komşuluk ilişkilerinin geliştirilmesi, üye ülkeler arasında karşılıklı saygı ve güven ilişkisinin geliştirilmesi ve işbirliğinin sağlanması (BSEC, 2020) olduğu görülmektedir. Bu bağlamda, KEI'nin bölgesel ekonomik işbirliği inşası, aynı zamanda üye ülkeler arasındaki siyasal dayanışmaya, barış ve güven ortamının tesis edilmesine, ülkeler arası siyasi sorunların ve bölgesel siyasi meselelerin çözümüne katkılar sağlamaktadır.

Ekonomik işbirliklerinin etkili ve başarılı olabilmesi açısından üye devletlerin ekonomik sistemlerinin uyumlu olması kadar siyasi sistemlerinin uyumlu olması da önemlidir. Üye devletlerin siyasi yapılarının uyumlu olması, işbirliği çerçevesinde kurumsal yapıların oluşumunu ve kurumsal işleyişi kolaylaştırarak ülkelerin uyum içinde çalışmasını sağlamaktadır. Ayrıca ekonomik işbirliği içinde entegrasyon süreçleri için gerekli olan güven ortamının ülkeler arasında inşa edilmesine katkıda bulunmaktadır (Karagül, 2014: 26). Bu bağlamda kurulan ekonomik işbirliklerinde ülkelerin siyasi konjonktürlerinin de önemli bir yere sahip olduğu söylenebilir.

Karadeniz Ekonomik İşbirliği Örgütü, kurulduğu yıldan itibaren üye devlet ve gözlemci devlet sayısını artırarak varlığını devam ettirmektedir. Örgütün kurucu üyeleri de dahil olmak üzere üye devletlerin hiçbirinin örgütten ayrılma yönünde eğilimi olmadığ 1 gibi örgüte yeni üye devletler alınmış ve üye olarak 2004 yılında Sırbistan katılmıştır. Ayrıca birçok ülke ve kuruluş gözlemci statüsüyle örgüte bağlı durumdadırlar. Böylelikle KEİ'nin üyelik ilişkileri içerisinde üye devletlerle olan siyasi ve diplomatik bağlarını güven içinde başarıyla koruduğu ve sürdürdüğü söylenebilir (Yalçınkaya, 2017: 13). Ancak örgütün üyesi konumunda bulunan ülkeler arasında çıkabilecek olası sorunlar için KEİ'nin güçlü yaptırım mekanizmalarının olmadığını da belirtmek gereklidir. 


\section{Ekonomik İlişkilere Etkisi}

Karadeniz Ekonomik İşbirliği Örgütü, bölgesel ekonomik işbirliği temelli olarak üye ülkelerin, ekonomik işbirliği çerçevesinde bölge ülkeleriyle ilişkilerinin geliştirilmesini sağlamayı amaçlayan bir yapılanmadır. Bu bakımdan örgüt ve örgüte üye ülkeler arasındaki ilişkilerde ekonomi önemli bir yere sahiptir. KEİ üyesi ülkelerin ekonomik gelişmiş̧lik seviyeleri birbirinden farklı düzeylerdedir. 1989 yılına kadar merkezi bir ekonomi anlayışı ve yönetime sahip olan ülkeler, küreselleşmenin de etkisiyle birlikte, hızlı bir dönüşüm sürecinden geçerek serbest pazar ekonomisi şartlarına uyum gösterme çabası içine girmişlerdir (Altıntaş, 2006: 652). Bu durumun bölge ülkelerinin dünya ekonomisine entegre olabilme kabiliyetlerini artırmasına, bölge ülkelerinin birbirleriyle olan ekonomik ilişkilerini yoğunlaştırmasına ve ticaret hacimlerinin yükselmesine yönelik katkılar yaptığı söylenebilir. Türkiye'nin 1991 yılı dış ticaret hacmi 34 milyon dolar olarak gerçekleşirken, 1992 yılında KEI'nin faaliyetlerine başlamasından bir sonraki yıl, 1993 yılı dış ticaret hacminin yaklaşık 45 milyon dolara yükseldiği görülmektedir (TUIK, 2020). Bu açıdan KEİ, üye ülkelerinin ekonomik ilişkilerine yaptığı olumlu katkılar Türkiye örneğinde görülmektedir.

Örgütün farklı dönemlerde gerçekleştirdiği zirve toplantılarında belirlediği hedeflerinin temeli oluşturulurken, üye ülkelerin birbirlerine olan coğrafi yakınlıklarının sağladığı avantajlar dikkate alınmış ve ülkelerin ekonomik açıdan karşılıklı olarak ihtiyaç duyduğu tamamlayıcı unsurlardan, işbirliği örgütü çerçevesinde yararlanmaları, ilişkilerin geliştirilmesine katkı sağlamıştır. Bölgenin bulunduğu coğrafi konum itibarıyla Avrupa, Asya ve Ortadoğu ülkelerinin geçiş güzergahında olması, ülkelerin ekonomik faaliyetlerinin canlılığının ve sürekliliğinin sağlanması açısından önemli avantajlar oluşturmuştur.

Karadeniz Ekonomik İşbirliği bölgesi, petrol ve doğalgaz rezervleri bakımından zengin yeraltı kaynaklarına sahip bir bölgedir. Hazar Havzası, 200 milyar varil seviyesindeki petrol yataklarının yanı sıra dünya doğalgaz rezervlerinin \%27'sini oluşturmaktadır. Bu bakımdan bölge, Körfez ülkelerinden sonra yeryüzünün en büyük petrol yataklarına ve doğalgaz rezervlerine sahip bir bölge olma özelliği taşımaktadır (Erkmenoğlu, 2001). Yaklaşık 19,5 milyon $\mathrm{km}^{2}$ lik alana ve 350 milyon gibi büyük bir nüfusa sahip olan KEİ, bugün dünya ticaretinin yaklaşık olarak \%5'ini gerçekleştirmektedir ve üye ülkelerinin dış ticaret hacmi yaklaşık 650 milyar dolardır (Şengül, 2009: 53). Karadeniz Havzası'nın yeraltı kaynakları bakımından zengin bir bölge olması, KEI'nin geçiş güzergahındaki konumu itibariyle sahip olduğu jeostratejik önemini artırarak çok daha değerli kılmaktadır. 
S.Bakan-M.E. Güven Karadeniz Ekonomik İsbirliği Örgütü (KEİ)...

KEI'nin amaçları çerçevesinde üye ülkelerinin ekonomik olarak birbirlerini tamamlayıcı nitelikte ilişkilere ve faaliyetlere öncelik vermesi, Sovyetlerden bağımsızlı̆̆ını yeni kazanmış üye ülkelerin ekonomik sistemlerinin de merkezi bir anlayıştan serbest ekonomik sisteme geçişini ve entegre olmalarını gerekli kılmaktadır. ${ }^{5}$ Çünkü üye ülkelerin benzer ekonomik sistem içeresinde hareket etmeleri hem ülkeler arasındaki ticari ilişkileri desteleyerek ülkelerin ticaret hacimlerinin büyümesine hem de örgütün ekonomik ve siyasi entegrasyonunu gerçekleştirmesine katkı sağlamaktadır.

KEİ'nin ekonomik entegrasyonunu gerçekleştirmeye yönelik oluşturduğu kurullar ve uyguladığı projeler; mevcut kaynakların etkin dağılımını ve kullanımını, rekabet alanlarının çeşitlenmesini, piyasa risklerinin azaltılmasını ve ar-ge harcamalarının artmasına katkılar yaparak verimlilik artışı sağlamaktadır (Şengül, 2009: 51-52). Bölgesel yatırımların gerçekleşmesi için üye ülkelere finansal kaynak ve gerekli altyapının sağlanmaya çalışılması, verimliliğin artırılması adına önemlidir. Bu amaçla kurulan Karadeniz Ticaret ve Kalkınma Bankası'nın 2016 yılı itibariyle yaklaşık 4,2 milyar dolarlık bir kaynăğ yönetmesi ve bölge politikalarını desteklemesi somut örnekler arasında gösterilebilir (Yalçınkaya, 2017: 12-13). Verimlilik artışıyla birlikte üye ülkelerin ekonomileri güçlenerek uluslararası piyasada rekabet edebilecek büyük firmalar oluşturabileceklerdir. Bu rekabet, üye ülkelerin verimlilik ve etkinlik düzeylerini yükseltecektir. Böylelikle, üye ülkelerin piyasa darlığı, döviz kıtlığı, tasarruf yetersizlikleri ve nitelikli işgücü eksikliği gibi ekonomik sorunlarının azaltılması sağlanırken aynı zamanda üye ülkelerin kalkınma düzeyleri hızlandırılacaktır (Çelik, 2005: 442-443).

\section{Sosyal ve Kültürel İlişkilere Etkisi}

Karadeniz Havzası, kapsadığı alan itibariyle oldukça geniş bir bölgeyi içinde barındırmaktadır. $\mathrm{Bu}$ bölgenin genişliğiyle birlikte bölge ülkelerin birbirlerine olan yakın konumları, bölge içindeki ülkelerin ve toplumların benzer kültür, gelenek, tarih ve deneyimlere sahip olmalarında etkili olmuştur. Bölge ülkelerinin kültürel, sosyal, dinsel ve tarihsel benzerliklerinin, ilişkiler üzerinde belirgin şekilde etkileri görünmese de bölge ülkelerinin etkileşimleri, örgütün entegrasyon süreci ve bölgesel işbirliği örgütünün başarıları üzerinde önemli etkileri ve katkıları bulunmaktadır (Çelik, 2005: 443). Bu bakımdan tarihi, kültürel ve dinsel bağlar, doğrudan doğruya ekonomik bütünleşmenin

\footnotetext{
5 KEİnin kuruluş yıllarına bakıldığı zaman üye devletlerden sadece Türkiye ve Yunanistan'ın serbest piyasa ekonomisine sahip olduğu, diğer ülkelerin Sovyetlerin dağılması sonrası ortaya çıktıkları, merkezi planlamaya dayalı bir ekonomilerinin olduğu ve özel sektör faaliyetlerinin olmadığı bir ekonomik yapı görülmektedir.
} 
gerçekleşme nedeni sayılmasa da ekonomik bütünleşmelerin oluşmasına ortam hazırlayan başlıca faktörler arasındadır (Hepaktan ve Çınar, 2011: 69).

Bölgesel işbirliklerinde üye ülkeler arasındaki tarihi, kültürel ve dini bağların bulunması ekonomik bütünleşmelerin oluşturulmasında etkili olmaktadır (Şengül, 2009: 9). Ekonomik gelişmişlik seviyeleri bakımından birbirinden oldukça farklı düzeylere sahip olan ülkelerin aynı bölgesel işbirliği örgütü içinde yer aldığ 1 görülebilmektedir. Bu bağlamda, Avrupa Birliği (AB) üye ülkelerine bakıldığı zaman ekonomik gelişmişlik seviyesi yüksek olan ülkeler ile ekonomik seviyesi çok daha düşük olan ülkelerin bir aradalığı görülmektedir. Bu açıdan entegrasyon sürecinde ülkelerin sahip oldukları ortak tarih, kültür ve din faktörlerinin göz önünde tutulması gerektiği ve önemli bir role sahip olduğu unutulmamalıdır.

Dünya üzerinde meydana gelen birçok mücadelenin temelinde kültürel, dini ve sosyal farklılıkların ön plana çıktığı ve etkili olduğu görülmektedir. Karadeniz Havzası içerisinde bulunan ülkeler, tarihsel süreçte birbirleriyle ticaret veya diğer nedenlerden ötürü çeşitli ilişkiler geliştirmişlerdir. Bu etkileşim ortamı aynı zamanda üye ülkeler arasında ortak noktaların oluşmasında etkili olmuştur. $\mathrm{Bu}$ bakımdan KEI üyesi ülkelerin tarihsel süreçte meydana getirdikleri ortak noktaların, ülkeler arasındaki karşılıklı güven ortamının tesis edilmesinde etkili olduğu söylenebilir (Karagül, 2014: 26).

Sovyetler Birliği’nden ayrılarak bağımsızlıklarını kazanan ülkelerin tarihsel süreç içerisinde bir arada bulunmalarının, sosyal, kültürel ve tarihi birçok ortak noktalarının oluşmasında etkili olduğu ve sonrasında da bu ortak noktaların ve bağların sürdürüldüğü görülmektedir. Diğer taraftan KEİ kurucu ülkesi olan Türkiye'nin, Sovyetlerden bağımsızlıklarını kazanan Türk Cumhuriyetlerle özellikle Azerbaycan vd.- ortak kültürel, dilsel, dinsel ve tarihi mirasa sahip olması bu ülkeler arasındaki ilişkileri daha güçlü hale getirmektedir. Dolayısıyla ülkeler arasında var olan ortak kültürel, sosyal ve tarihi bağların, bölgesel işbirlikleri altında tek çatıda toplanan ülkelerin, etkileşim düzeyini daha fazla artırmakta ve bölgesel işbirliği örgütlerinin başarısı üzerinde olumlu katkılar yapmaktadır.

\section{KEI'NINN BÖLGESEL SORUNLARIN ÇÖZÜMÜNDEKİ ETKİSI}

Soğuk Savaş döneminin ardından uluslararası sistemin blok yaklaşım anlayışı sona ererken, Balkanlar gibi bölgesel alt sistemlerde yeni dönemle birlikte sancilı süreçler yaşanmaya başlamıştır (Özlem, 2017: 100). Balkanlar ve Kafkasya'da yaşanan sorunlar, bölgeyi gerilim ve çatışma bölgesi haline getirmiştir. BosnaHersek ve Kosova Bunalımları, Azerbaycan topraklarının Ermenistan tarafindan işgali (Altıntaş, 2006: 640) ve bloklaşma döneminin iki tarafi olan ABD ve Rusya'nın Balkanlar, Ortadoğu ve Kafkasya bölgeleri üzerindeki politikaları da 
S.Bakan-M.E. Güven Karadeniz Ekonomik İsbirliği Örgütü (KEİ)...

bu gerilimleri daha fazla artırmıştır. Bu gelişmeler üç önemli stratejik bölgenin ortasında bulunan ve geçiş güzergahları üzerinde yer alan Karadeniz Havzası'na, jeostratejik açıdan daha fazla önem kazandırmıştır.

Karadeniz Ekonomik İşbirliği Örgütü (KEİ) üyesi ülkelerin bölgesel coğrafi yakınlıklarının meydana getirdiği olumlu yansımaların yanı sıra, tarihsel süreç içerisinde üye ülkelerin farklı nedenlerden ötürü siyasi, ekonomik ve kültürel çatışma durumları da bulunmaktadır. Üye ülkeler arasında yaşanan; Azerbaycan ve Ermenistan arasındaki savaş gerginliği, Ermenistan'ın Türkiye'ye yönelttiği asılsız soykırım iddiaları ve toprak talebi, Türkiye ile Yunanistan arasında uzun zamandır devam eden Kıbrıs ve Ege Adaları sorunu, Gürcistan'ın Güney Osetya ve Abhazya bölgelerinin birleşme politikalarının ortaya çıkardığı bölgesel kaos, Rusya ve Ukrayna arasındaki Kırım meselesi ve yine Rusya, Ukrayna ve Moldova arasında tampon bölge olan Trans-Dinyeper sorunu (Şengül, 2009: 46), Romanya ve Ukrayna arasında 2. Dünya Savaş'ından kalan sınır sorunu ve diğer mevcut sorunlar, Karadeniz Havzası'nda bulunan KEİ üyesi ülkelerin arasında yaşanan sorunlardır. Ayrıca Yukarı Karabăg ve Kuzey Kıbrıs Türk Cumhuriyeti'nin statüleriyle ilgili durumların Karadeniz ülkelerini yakından ilgilendirmesi ve bölge ülkelerinin bu süreçlerin tarafı konumunda olması, KKTC ve Karabağ sorunlarını, Karadeniz bölgesinin birer sorunu haline getirmektedir (Kamalov, 2009: 17-19).

KEİ üyesi ülkeler arasında yaşanan söz konusu sorunların değerlendirilmesinin yapılması ve çözüm olanaklarının sağlanması adına KEİ anlaşmasının 1. maddesinde, ülke halklarının barış ve güvenlik oluşturmaya yönelik kararları dikkate alınarak, bu köklü sorunların çözüme kavuşturulması için en kısa zamanda ortak girişimler başlatılması amaçlanmıştır. Bu amaçla, barışın ve güvenliğin tesis edilmesi ve istikrarında sağlanması için, Karadeniz Bölgesi Barış ve Güvenlik Birliği ve Karadeniz Güvenlik Konseyi kurulmuştur (Şengül, 2009: 46). KEİ, kuruluş itibariyle ekonomik işbirliği amacını öngörse de, bu amacın gerçekleşmesi yoluyla bölge ülkelerinin güvenliğine de büyük katkılar sağlamaktadır. Soğuk Savaş döneminin genel özelliği olan; ülkelerin kendi içlerine çekilmesi, kapalı bir ekonomi sistemi benimsemeleri, komşu ülkelerin güvenlik ikilemi içerisinde birbirlerini potansiyel tehlike ve düşman olarak görmeleri ve kronikleşmiş güvenlik kaygıları bölge ülkelerini birbirlerinden uzaklaştırmıştır. Bölgede oluşturulan ekonomik kurumsal yapılanma (KEI), mevcut sorunların görüşülerek taraf ülkeler arasında sorunların çözülmesi için büyük imkân sunmakta, ekonomi başta olmak üzere üye ülkeler arasında siyasi ve kültürel ilişkilerin de gelişmesi için zemin hazırlamaktadır (Aşık, 2010: 38).

KEI'nin bölge ülkeler arasında mevcut sorunların çözümünde önemli bir yere sahip olduğu düşünülebilir. Ancak bu sorunları nihai çözüme kavuşturarak 
ortadan kaldıracak bir yapıya ve etkiye sahip olmadığı da bir gerçektir. $\mathrm{Bu}$ bakımdan, Sovyetler Birliği'nin dağılması sonrası Azerbaycan ve Ermenistan arasında yaşanan sorunların çözümünde nihai bir etkisinin ve yaptırım mekanizmalarının olduğu söylenemez. Ancak iki ülkenin örgüte üye olarak aynı çatı altında ekonomik ilişkilerini sürdürmeleri, ekonomik ilişkilerin ve kurulan ekonomik birlikteliklerin ülkelerin aralarındaki siyasi ilişkilere yapacağı olumlu katkılar açısından düşünüldüğünde, ekonomik işbirliği örgütü KEİ'nin, üye iki ülke arasındaki ilişkiler üzerinde düzenleyici etkisinin varlığını göstermesi bakımından önemlidir.

\section{AKDENIZ'DE İŞBİRLİĞí'NIN KURULMASI ÜZERINE BİR DEĞERLENDİRME}

Dünyada yaşanan gelişmelere bağlı olarak mevcut aktörlerin değişen rolleri ve yeni aktörlerin yeni rol istekleri ve kendilerini yeniden tanımlanma çabası, aktörlerin yer aldığı sahnelerinde değişmesine neden olmaktadır. Akdeniz'in artan önemi, bölge ve dünya ülkelerinin bölgeye dair yeni senaryolar üretmesine neden olurken, Türkiye'nin de bölgesel ve küresel aktör olma vizyonu çerçevesinde bölgesinde yaşanan gelişmeleri yakından takip ederek, rolünü ve yerini bölgesel düzeyde dahi olsa sağlamaya çalışmak zorunda hissettiği görülmektedir.

$\mathrm{Bu}$ bağlamda Türkiye'nin; yakın kara ve deniz coğrafyasına kayıtsız kalmaması ve bölgedeki huzur ve güvenliğin tesisinin sürdürülmesi, küreselleşmenin ve küresel güçlerin olumsuz etkilerinin azaltılması ve bölgede ülkelerarası işbirliklerinin geliştirilmesi amacıyla bölgesel bir oluşumun inşasında önemli roller üstleneceği düşünülebilir.

Tarihsel süreç içerisinde Akdeniz Havzası'na ilişkin olarak birçok defa işbirliği denemeleri yapılmıştır. Ancak bu denemeler yeterince etkili olmamış ve sürdürülebilir kılınamamıştır. Dolayısıyla Akdeniz Havzası'nda gerçekleştirilecek KEİ benzeri bir ekonomik işbirliği birlikteliğinin, Akdeniz coğrafyasında yaşanan gelişmelerle birlikte meydana gelen değişim ve dönüşüm dinamikleri ve bölge ülkelerinin ekonomik, siyasi ve sosyo-kültürel yapıları dikkate alınarak değerlendirildiğinde, Karadeniz Havzası'na nazaran ekonomik açıdan daha güçlü bir yapı ortaya koyacağ 1 bir gerçeklik olarak önümüzde durmaktadır.

Akdeniz Havzası, tarihsel süreç içerisinde yüzyıllar boyunca insanlık tarihinin en önemli dönüm noktalarından biri konumunda olmuştur. Bu durum üzerinde Akdeniz Havzası'nın sahip olduğu ekonomik, siyasi ve sosyal yapısının ve jeostratejik konumunun etkileri bulunmaktadır. Asya, Afrika ve Avrupa kıtalarını bir arada buluşturan konuma sahip olan Akdeniz Havzasi; deniz ticareti yolları üzerinde Cebelitarık ve Süveyş kanalı gibi iki önemli deniz geçiş güzergahına 
S.Bakan-M.E. Güven Karadeniz Ekonomik İsbirliği Örgütü (KEİ)...

sahip olması ve Kuzey Afrika ve Güney Avrupa'nın da dahil olduğu çok geniş bir alanı kapsamasıyla birçok farklı medeniyete ve kültüre ev sahipliği yapması açısından önemini korumuştur.

Akdeniz Havzası, Doğu ile Batı'nın buluştuğu siyasi, ekonomik, sosyokültürel ve beşerî ilişkilerin ve alış-verişlerin gerçekleştiği bir kavşak noktası olmuştur. Havzanın, sahip olduğu özelliklerinin yanı sıra enerji nakil yollarının kesişim noktası üzerinde olması son dönemlerde bölgenin jeostratejik önemini artıırken Akdeniz'i uluslararası sistemin güç merkezleri için daha cazibeli kılmış ve Akdeniz'i vazgeçilmez bir bölge konumuna getirmiştir. Akdeniz Havzası, ülkelerinin sahip olduğu coğrafi özellikler bakımından yaklaşık 2,5 milyar $\mathrm{km}^{2}$ 'lik deniz alanı ve 8,5 milyon $\mathrm{km}^{2}$ 'lik karasal alana sahip olmakla birlikte yaklaşık 504 milyon insanın yaşadığı geniş bir alanı kapsamaktadır.

Akdeniz'in önemi, Avrupa Birliği’nin genişleme sürecinin bir yansıması olarak da ön plana çıkmaya başlamış, özellikle Avrupa Birliği'nin kuruluşundan itibaren Fransa'nın politikaları içinde yer almıştır. Bu durum üzerinde Avrupa Birliği'nin kuruluşunda Fransa'nın, Avrupa'da batı blokunu çatlatmadan Almanya'nın etkisinden kurtulmak için bir ara yol bulma çabasının, ABD ve İngiltere'den bağımsız bir yapılanma girişimi amaçlamasının ve post-modern kolonyal emelleri (zihniyet) çerçevesinde hareket etmesinin etkili olduğu söylenebilir.

1947 yılından itibaren İngiltere, sömürgeleriyle olan ilişkilerini sonlandırırken diğer taraftan sömürge devletleri bağımsızlıklarını ilan etmeye başlamıştır. $\mathrm{Bu}$ durum İngiltere'nin sömürgelerinden elde ettiği iktisadi faydanın azalmasına yol açmış ve İngiltere'yi yeni arayışlara sevk etmiştir. Başlangıçta Avrupa'da yeni oluşturulan topluluk içinde yer almayı istemeyen İngiltere, işlevselci düşüncesi çerçevesinde Avrupa Serbest Ticaret Bölgesi'ni -EFTA'yı (European Free Trade Association) meydana getirmiştir.

EFTA ile istediği sonucu elde edemeyen İngiltere, topluluğa başvuru talebinde bulunmuş olsa da Fransa bu talebi bir tehdit olarak algılamıştır. Fransa Cumhurbaşkanı De Gaulle'ün Avrupa bütünleşmesine yönelik aşırı ulusalcı yaklaşımı nedeniyle İngiltere'nin 1962 ve 1967 yıllarında 2 kez yaptığı topluluğa girme talebi reddedilmiştir (Tezcan, 2016: 14).

İngiltere'nin Avrupa'da yeni meydana gelen bu yapıyla başlangıçta birlikte hareket etmemesinde Fransa'nın daha yoğun ve ilerlemeci bir örgüt oluşturma isteğinin etkili olduğu söylenebilir. Bu bakımdan Fransa, mevcut sorunların çözümünün de sağlanması adına federal bir yaklaşımla (Karakaş, 2002: 12-16) kurumların ve kuralların daha etkili olduğu bir yapı öngörürken; İngiltere ise Fransa'nın bu yaklaşımının tersine (Çakır, 2001: 15-16), temel öncelikleri siyasi antlaşmalar ve kurumsal yapılar olan bir yapı yerine, daha bütüncül ve işlevselci 
(fonksiyonel) bir yaklaşımdan (Karakaş, 2002: 16), İngilizlerin deyimiyle 'güçsüz olmayan fakat gevşek' (loose but not weak) bir oluşumdan, yana olmuştur. İngiltere'nin, Avrupa Birliği' ne sonradan katılım nedenini, AB'nin güç durumunu yakından kontrol etmek amaçlı olarak denetleyici işlevde hareket etmek isteği olduğu söylenebilir.

1962 yılında İngiltere'nin EFTA'yı kurması üzerine AB'nin genişleme yönü değişmiş ve Fransa güneye yönelerek Akdeniz'i ticaret gölü haline getirmeyi amaçlamıştır. Ayrıca 1967 yılında yaşanan Arap-İsrail Savaşı, sonraki yıllarda yaşanan gelişmeler ve meydana gelen petrol krizi, İngiltere'yi Kuzey Denizi'nde petrol arama çalışmalarına yöneltmiştir. $\mathrm{Bu}$ durum, $\mathrm{AB}$ üye ülkelerini yeni arayışlara yönlendirmiş ve $\mathrm{AB}$ 'nin genişleme süreçlerinin şekillenmesi üzerinde etkili olmuştur.

Avrupa Birliği'nin genişleme sürecinde yaşanan genişleme dalgaları sonrası; birinci dalganın sonucu 1973 yılında İngiltere, İrlanda ve Danimarka'nın ikinci genişleme dalgasıyla birlikte 1981 'de Yunanistan'in ve üçüncü genişleme dalgasıyla 1986'da İspanya ve Portekiz'in AB'ye katılımları, bir taraftan AB'nin Akdeniz'e yönelimi zorunlu kılarken diğer taraftan "Bütünleşmiş Akdeniz Programı”nın işlerlik kazanmasını sağlamış ve Avrupa Birliği'nin yönünü yeniden Akdeniz'e çevirmesini sağlamıştır (Williams, 1996: 73). Akdeniz, Avrupa Birliği'nin genişleme sürecinin ve sonrasında günümüze kadar ulaşan ve devam eden politikalarının vazgeçilmez alanı haline gelmiştir.

1989 yılında Berlin Duvarı'nın yıkılması sonrası Almanya'nın ikili yapısının yeniden şekillenmesi ve 1991 'de Sovyetler Birliği'nin dağılması sonrası Avrupa'nın geleceğinin yeniden belirlenmeye çalışılması, AB'nin Doğu Avrupa ülkeleriyle ilişkilerinin yoğunlaşmasını sağlanmıştır. Bu açıdan Avrupa Akdeniz Ortaklığ 1 düşüncesinin, AB'nin Doğu Avrupa'ya yönelik genişleme hareketinin dengeleyici bir unsuru olduğu da söylenebilir (Çeşmecioğlu, 2003: 18-20). AB'nin genişleme sürecinin ağıllıklı yönünün hangi bölgeye ilişkin olacağ 1 konusunda topluluğun iki önemli üyesi olan Almanya ve Fransa arasındaki fikir ayrılığ 1 bu süreçte etkili olmuştur. Almanya'nın daha çok Orta ve Doğu Avrupa'ya yönelik ağırlık veren bir bütünleşme politikası izlemesi, Fransa'nın politikalarıyla ters düşmüştür. Dolayısıyla AB'nin Akdeniz politikası, Almanya'nın bu politikasına "karşı güç" ve denge oluşturma çabası içinde geliştiği söylenebilir (Tınar, 1998: 34-35). Bu bağlamda Fransa'nın tarih boyunca sürdürdügü politikalarında gündem belirleyicilik gücünden yoksun olarak sürekli bir tepki politikası yürüttüğü ve sömürge gücü olduğu dönemlerin izlerini taşıyan politika anlayışını devam ettirdiği ve bu yönde hareket ettiği söylenebilir.

1989 yılında Berlin Duvarı'nın yıkılmasına neden olan küresel politik değişimler, Avrupa Birliği'nin stratejik ve jeopolitik önceliklerini revize etmesini 
S.Bakan-M.E. Güven Karadeniz Ekonomik İsbirliği Örgütü (KEİ)...

sağlayarak güney yönlü bir derinleşme sürecinin başlamasına neden olmuştur. 1990 yılında Avrupa Konseyi, 1992-1996 yılları arası dönemi kapsayacak şekilde "Yenileştirilmiş Akdeniz Politikası"nı (YAP) ortaya koyarak bu politikalar doğrultusunda kararlar almaya yönelmiştir (Kahraman, 2008: 1733). Bu kapsamda, konsey yapılan öneriler çerçevesinde Akdeniz ülkelerine yönelik yaptığı mali yardımları, 1992-1996 yılları arası dönemde yaklaşık iki kat artırmıştır (Kurtbağ, 2003: 79). Avrupa Birliği'nin Akdeniz politikalarının temelinde çok boyutlu karşılıklı bağımlılık ilişkilerinin ve Sovyetler Birliği’nin dağılması ve Körfez Savaşı'nın etkisiyle bölgede oluşan boşluğu, AB'nin güvenlik ve istikrar ihtiyacı çerçevesinde doldurma isteğinin olduğunu belirtmek gereklidir (Tınar, 1998: 33-35). Bu bağlamda AB'nin bölgede oluşan boşluğu ABD'nin doldurmasının önüne geçmek ve Arap-İsrail Savaşı'nın bölgede oluşturduğu olumsuz yansımaların bölge ülkelerini etkilememesi ve ticari ilişkilerin sürdürülebilir kılınmasını sağlamak amacının olduğu söylenebilir.

1994 yılında başlayan ve farklı ülkelerde gerçekleştirilen zirve toplantıları sonrası 1995 yılında Barselona'da toplanan 15 üye ülke ve 11 Akdeniz ülkesi 'Barselona Bildirisi'ni kabul etmiştir. Böylelikle AB'nin sıkışan Akdeniz politikasını genişletmeyi ve Akdeniz'de siyasi, sosyo-kültürel ve ekonomik alanlarda diğer ülkelerle bütünleşmeyi hedeflediği söylenebilir (Kurtbağ, 2003: 82). Türkiye'de 1995 yılında Barselona Konferansı kapsamında başlatılan ve Avrupa-Akdeniz Ortaklık sürecinin devamı olan 'Akdeniz için Birlik' kuruluşuna 2008 yılında üye olmuş, Akdeniz'de işbirliğinin geliştirilmesi ve güçlendirilmesine yönelik olarak etkin şekilde katkıda bulunmaya çalışmaktadır (T.C. Dışişleri Bakanlığı, 2020a).

Barselona Konferansı'yla "Yeni Avrupa-Akdeniz Ortaklığı" süreci başlatılmış ve bu süreçle birlikte Akdeniz Havzası ekonomi, dış politika ve güvenlik konuları açısından doğrudan ilgi alanı içine alınmıştır. Fransa'nın iki hatlı Avrupa düşüncesi kapsamında değerlendirilebilecek olan "Akdeniz için Birlik” fikri "Akdeniz Birliği” adıyla ilk defa Fransa Cumhurbaşkanı Nicolas Sarkozy tarafından gündeme getirilmiştir. Buna göre Akdeniz'e kıyısı olan AB üyesi ülkelerle Akdeniz'e kıyısı olan Kuzey Afrika ülkeleri arasında birlik oluşturulması fikri önerilmiş̧ir (Karluk, 2014: 262-263). Ancak Avrupa-Akdeniz Ortaklığ 1 çerçevesinde oluşturulan düşüncelerin, planlandığ 1 şekliyle ülkelerin siyasi, ekonomik, hukuki, mali ve sosyal açıdan amaçlarını tam olarak karşılayamadığı ve gerçekleştiremediği görülmektedir (Gündüz, 2012: 155-162). Bu bağlamda oluşturulan birlik fikrinin arkasında Fransa'nın sahip olduğu postkolonyal anlayışını medenileştirme rüyaları adı altında sürdürme, sömürge sahibi olduğu dönemlerdeki gücünü yeniden elde etme ve Doğu Akdeniz ve Ortadoğu'da liderliği üstlenebilme ve kontrolü ele geçirebilme çabası içinde olduğu söylenebilir (Y1ldı, 2009: 80). 
Avrupa Birliği'nin Akdeniz’e yönelik olarak mağrip (Fas, Tunus ve Cezayir) ve maşrık (Suriye, Lübnan ve Mısır) ülkeleriyle geliştirdiği ilişkiler kolektif düzenlemelerden çok ikili anlaşmalar şeklindedir. Bu ilişkilerin şekillenmesinde ise sömürgecilik döneminin etkilerinin fazla olduğu söylenebilir (Williams, 1996: 69). $\mathrm{Bu}$ açıdan $\mathrm{AB}, \mathrm{Akdeniz}$ 'in doğusu ve güneyindeki ülkelerle geliştirdiği ilişkilerini, geçmiş dönemlerde kurduğu sömürgecilik ilişkileri üzerine yeniden gerçekleştirmeye çalışmaktadır (Bensidoun and Chevallier, 1997: 8). Böylelikle Akdeniz'e hâkim olarak Akdeniz'in bir ticaret gölü haline getirilmesi amaçlanmaktadır. Bu durum üzerinde, Avrupa Birliği'nin kuruluşunda önemli bir yere sahip olan Roma Antlaşması'nın (AB Genel Sekreterliği, 2011), Dördüncü ve Beşinci kısmında yer alan ilgili hükümlerin, üye ülkelerin ilişkilerini yeniden düzenleyerek diğer ülkelerle ikili anlaşmalar ve işbirlikleri sağlanmasına olanak tanıyan maddelerin etkili olduğu söylenebilir.

AB'nin Akdeniz politikasının temelinde, Akdeniz'in önemli bir coğrafi alanı kapsaması nedeniyle havzanın oluşturduğu karşılıklı bağımlılık ilişkilerinden ve tercihlerden yararlanmak olduğu söylenebilir. AB, Akdeniz ülkeleri için büyük bir ihracat pazarı konumunda iken, $\mathrm{AB}$ ise enerji ithalatının önemli bir bölümünü bu bölgeden sağlamaktadır (Akder, 1998: 6). Bu açıdan Avrupa Birliği, petrol ve doğalgaz ağırlıklı enerji ithalatının yaklaşık dörtte birini Akdeniz Havzası'nda bulunan ülkelerden elde etmektedir (Tinar, 1998: 33).

Türkiye'nin ise Avrupa Birliği’yle ilişkileri aynı zamanda AB'nin tanımlamış olduğu Akdeniz politikaları kapsamında belirtilen sınırlar içindeki konumu itibariyle şekillenmiş̧tir (Williams, 1996: 65). Bu kapsamda Türkiye’nin AB ile ilişkilerinin "İmtiyazlı Ortaklık" antlaşmaları çerçevesinde şekillenmesinin ve gerçekleştirilmesinin amaçlandığı söylenebilir. Ancak Türkiye'nin AB ile ilişkileri mağrip ve maşrık ülkelerinden daha farklıdır. Türkiye'nin ticari liberalizasyonunu sağlamış olması, $\mathrm{AB}$ üyelik sürecini geliştirmesi, jeostratejik konumu ve bölge ülkelerine kıyasla nüfus itibariyle de güçlü bir ülke olması bu ilişkileri farklı kılmaktadır.

Akdeniz'in önemi Avrupa Birliği ülkeleri için oldukça fazladır. Türkiye'nin Akdeniz'e yönelik politikaları bir yandan AB'nin ve diğer güçlerin bölgeye yönelik politikalarını etkileyecek ve yeniden şekillendirecektir. Karadeniz'de ekonomik bir işbirliği ortamının oluşturulmasında; bölgedeki jeostratejik önemi, dünya piyasasına ekonomik sistemiyle entegre olması ve ülkeler arası karşı1ıklı bağımlılık ilişkilerini iyi yönetmesiyle Türkiye ön plana çıkarak etkili olmuştur.

Türkiye, KEİ'nin daha aktif hale getirilmesini sağlayarak, doğrudan müdahil olmadan etki oluşturabileceği bir örgüt aracılığıyla Balkanlarda nüfuz gücünü artırdığı (Baharçiçek, 2020: 72) gibi Akdeniz'de de benzer bir politika yürüterek 
S.Bakan-M.E. Güven Karadeniz Ekonomik İsbirliği Örgütü (KEİ)...

oluşturulacak bir işbirliği yapılanmasıyla bölge ülkeleriyle ilişkilerini daha fazla geliştirebilir ve Akdeniz'de etki alanını genişletebilir.

Türkiye'nin sahip olduğu jeostratejik konumu itibariyle Karadeniz'de oluşturduğu etki alanından daha fazlasını Akdeniz'de oluşturulacak birlikteliğgin kurulması sürecinde elde edebilir. Bu bakımdan Akdeniz Havzası'nın; deniz ticareti geçiş güzergahında bulunması ve önemli petrol ve enerji kaynaklarına yakın olması bölgeyi değerli kılmaktadır. Ortadoğu'da ve yakın çevresindeki gelişen olaylara seyirci kalmayarak oyuncu konumunda rol almak isteyen Türkiye için Akdeniz'de bölgesel işbirliği örgütünün oluşturulması ve örgütün kuruluşunda etkin olarak yer alması oldukça önemlidir. Bu durum, aynı zamanda Türkiye'nin Doğu Akdeniz politikalarında önemli bir yere sahip olan Kıbrıs'ın, ulusal güvenliği ve bekası içinde önem arz etmektedir. Doğu Akdeniz'de; Mısır, Tunus ve Libya'da yaşanan gelişmelerin, Akdeniz Havzası'nda suların ısınacağını ve bölgenin öneminin daha da artacağını ortaya koymaktadır.

Akdeniz Havzası'na yakın ve Akdeniz'e sınırı olan ülkelerin yer aldığı bölgenin coğrafik ve ekonomik özelliklerinin birbirine alternatif ve tamamlayıcı niteliklere sahip olması, örgütün kurulma aşamasına önemli katkılar sağlayacaktır. Akdeniz'de kurulacak bir ekonomik işbirliği alanı, aynı zamanda Kuzey-Güney ülkeleri arasında bölgesel ekonomik entegrasyonun sağlanması açısından önemli bir yere sahip olacaktır. Bölge ülkelerinin yakın tarihi geçmişinin ortaklığı ve kültürel özelliklerinin benzerlikler taşıması ise örgütün varlığının ve sürekliliğine olumlu katkılar sağlayacaktır.

Akdeniz Havzasının bulunduğu konumu itibariyle sahip olduğu jeo-stratejik önemi, ülkelerin çıkar çatışma noktaları haline gelmesinden ziyade uzlaşma ve işbirliği noktasına dönüştürülmesi, ekonomik işbirliklerinin gerçekleşmesiyle sağlanabilir. Bu açıdan Türkiye'nin bölgede $\mathrm{AB}$ ülkelerinden farklı olarak sıfır sonuçlu oyunlar (zero sum games) yerine kazan-kazan (win-win) formülasyonu üzerine kurduğu ve sürdüreceği politikalar bölge ülkeleriyle kuracağı ilişkileri güçlendirecektir. $\mathrm{Bu}$ bakımdan Akdeniz'de Türkiye öncülüğünde kurulacak bölgesel bir işbirliği örgütünün, bölgenin sorunlarını çözmeye yönelik gerçekleştireceği çalışmalar, karşılıklı olarak bölge ülkelerinin ve bölgenin ekonomik olarak kalkınmasına yardımcı olurken aynı zamanda bölgenin huzur ve refahına katkılar sağlayacaktır.

\section{SONUÇ}

Türkiye Cumhuriyeti, kurulduğu günden itibaren bölgesel ve küresel nitelikteki örgütlere üye olma çabası içine girmiş, birçok siyasi ve ekonomik örgüte üye olmuştur. Türkiye'nin üyesi olarak bulunduğu örgütlerle ilişkisine bakıldığı zaman; örgüt üyesi olan devletlerle sahip olduğu tarihi yakınlık, kültürel derinlik ve coğrafi konum gibi özelliklerinin, ortak noktalarının fazla olması, üye 
ülkelerle arasındaki ilişkileri dolayısıyla da örgütle olan bağları üzerinde belirleyici etkiler yaratmaktadır.

Türkiye bulunduğu coğrafi konumu itibariyle sahip olduğu jeostratejik önemi, yakın kara ve yakın deniz havzasının sağladığı olağanüstü avantajları değerlendirmesi ölçüsünde değerli ve yararlı olacaktır. Bu bakımdan Türkiye’nin Asya ve Avrupa arasında köprü görevi görmesi ve bulunduğu konumu itibariyle hem Ortadoğu hem Karadeniz hem de Akdeniz ülkesi olması, Türkiye'nin vazgeçilmez bir aktör olarak bölgesel ve küresel örgütlerin içinde yerini almasını ve yeni örgütlerin kurulmasında öncülük etmesini sağlayacaktır. Karadeniz bölgesine ilişkin olarak Karadeniz Ekonomik İşbirliği Örgütü (KEİ) ile bölge/üye ülkeler ile geliştirdiği ekonomik, siyasi ve kültürel ilişkilerin sürekliliğinin sağlanmasında ve uygulamaların başarısında Türkiye'nin örgütün kurucu üyesi olarak yer alması önemli bir örnektir. Ayrıca Türkiye'nin birçok örgütte (NATO, Ekonomik İşbirliği Teşkilat1, G-20, D-8, İslam İşbirliği Teşkilatı, İktisadi İşbirliği ve Gelişme Teşkilatı (OECD), Avrupa Güvenlik ve İşbirliği Teşkilatı (AGITT) vd.) aktif ve etkili konumuyla yerini aldığı görülmektedir.

Karadeniz Ekonomik İşbirliği Örgütü, üyelerinin coğrafi, ekonomik ve siyasi özelliklerinin birbirlerine yakın ve benzer niteliklerinin bulunması önemli avantajlar oluşturmaktadır. Bu açıdan ekonomik işbirliği örgütlerinin üye ülkelerinin birbirleriyle olan ilişkilerinde; ülkelerin birbirleriyle karşılıklı olarak tamamlayıcı unsurlara sahip olması bağımlılık ilişkisini güçlendirirken, aynı zamanda üye ülkelerin yakın coğrafyaya sahip olmaları, ülkelerin siyasi ilişkiler geliştirmeleri yönüyle olumlu katkılar sunmaktadır. Bu bakımdan Karadeniz Ekonomik İşbirliği Örgütü üye ülkelerinin, yakın tarihi geçmiş, kültürel özellikler ve coğrafi yakınlıklara sahip olması, örgütün kurulmasında etkili olurken ekonomik yapıları ve amaçları bu ülkelerin birbiriyle olan ilişkilerinin tamamlanmasında kurucu rol oynadığı söylenebilir.

Akdeniz'de oluşturulacak bir ekonomik işbirliği örgütünün; üye ülkeler arasında ekonomik, siyasi ve kültürel ilişkilere katkı sağlayacağı, mevcut bölgesel sorunların bölgesel işbirliği içindeki etkili kurumlar aracıllğıyla çözüme kavuşturulacağ 1 ve bölgenin huzur ve refahına yönelik olumlu katkılar sunacağ 1 ön görülmektedir. Bu açıdan bölge ülkelerinde yaşanan siyasi istikrarsızlıkların ve krizlerin bölgede güven ve refah istikrarının sürekliliğini negatif yönde etkilediği söylenebilir. Yaşanan olumsuzlukların ortadan kaldırılması için uzun yıllar verilen mücadelelerin ve siyasi düzenin sağlanmasına yönelik çalışmaların bir netice vermediği de görülmektedir.

Bölgesel siyasi ve ekonomik istikrarın gerçekleştirilmesine yönelik olarak Akdeniz Havzası'nda bölge ülkeleriyle birlikte Türkiye'nin de aktif olarak yer alacağı ekonomik işbirliği ve konsorsiyum çalışmalarının, bölgenin siyasi 
S.Bakan-M.E. Güven Karadeniz Ekonomik İsbirliği Örgütü (KEİ)...

huzuruna ve ekonomik istikrarına olumlu çıktılar üreteceği söylenebilir. Türkiye'nin Akdeniz'de meydana getirilecek bir örgüt yapılanmasında kurucu rol üstlenmesi, bölge ülkeleriyle olan tarihi, kültürel ve sosyal bağları kapsamında düşünüldüğünde, Fransa öncülüğünde $\mathrm{AB}$ 'nin yürüttüğü Akdeniz politikalarından daha fazla etki alanı oluşturacaktır. Bu avantajlı durum, aynı zamanda bölgesel işbirliği örgütünün kurulmasını kolaylaştırdığg gibi bölge ülkeleri arası ilişkilerin sürdürülebilirliğine de yüksek katkılar sağlayacaktır.

KEİ'nin, üye ülkelerine bölgesel işbirliği sahası sunması ve üye ülkelerin münhasır alanlarında çatışmaksızın çalışmalar yürütme imkanı sağlaması, örgütün bölgesel ilişkiler üzerinde düzenleyici etkiler oluşturduğunu göstermektedir. Bu açıdan Türkiye'nin Karadeniz'de, münhasır deniz alanları içinde, enerji kaynaklarına yönelik yaptığı araştırmalar ve girişimler sonucu doğalgaz rezervlerine ulaşması, KEI üyesi ülkeler arasında bir çatışma alanı oluşturmamıştır. Bu bağlamda, Türkiye'nin girişimleri sonucu Akdeniz'de kurulacak bölgesel ekonomik işbirliği örgütü, KEI'de olduğu gibi üye ülkelerinin işbirliği içinde hareket etmesini sağlayacaktır. Böylelikle ülkelerin münhasır alanlarda yürüttükleri çalışmalarında diğer ülkelerle oluşabilecek çatışma alanları, bölgesel işbirliği örgütünün ilişkiler üzerindeki düzenleyici etkisiyle işbirliği alanlarına dönüşecektir.

Türkiye, bölgesel ve küresel sistem içerisinde aktif bir güç olarak rol almak istiyorsa tarih boyunca önemi üst düzeyde olan Akdeniz'e yönelik politikalarında, yakın çevresiyle ilişkilerinde ve yaşanan krizlerin çözümünde daha etkin ve rol üstlenici pro-aktif bir politika yürütmeyi amaçlamalıdır. AB'nin tarihsel süreçte Akdeniz Havzası'na ilişkin sürdürmekte olduğu politikalar, Akdeniz'de özellikle Türkiye'nin dış politikalarıyla çatışmakta ve Türkiye'nin bölge ülkeleriyle ilişkilerinde önüne birer engel olarak çıkmaktadır. Bu bakımdan Yunanistan ile yaşanan Ege Adaları sorunu, Kıbrıs Adas1 sorunu ve enerji kaynakları açısından bölge ülkelerinin Doğu Akdeniz'de yaşadıkları gerilimlerin bölgesel işbirliği örgütü çerçevesinde yeniden değerlendirilmesi, mevcut sorunların çözümünde etkili olacaktır.

Değişen dünyada değişen enerji kaynaklarıyla birlikte petrolün önemini yitirmeye başlaması ve yeni enerji kaynaklarına yönelimlerin artması özellikle enerji kaynakları bakımından zengin Doğu Akdeniz'i bir çekim merkezi haline getirmektedir. Akdeniz'de Türkiye'nin de içinde yerini aldığı bölgesel nitelikte bir ekonomik işbirliği ilişkiler ağının oluşturulması, bölge ülkelerinin siyasi ve ekonomik ilişkileri üzerinde yapıcı sonuçlar ortaya çıkaracaktır.

\section{KAYNAKÇA}

AB Genel Sekreterliği (2011). T.C. Başbakanlık Avrupa Birliği Genel Sekreterliği:https://www.ab.gov.tr/files/pub/antlasmalar.pdf (28.09.2020). 
Akder, H. (1998). Avrupa Birliği'nin Akdeniz politikası: nedenleri, hedefleri, araçları ve Türkiye'nin AB'nin Akdeniz politikasındaki yeri. Avrupa Birliği'nin Akdeniz Politikası ve Türkiye, Friedrich Ebert Stiftung, 5-29.

Alkan, A. (2006). 21. Yüzyılın ilk çeyreğinde Karadeniz güvenliği, Nobel Yayın Dağıtım.

Altıntaş, H. (2006). KEİB: Karadeniz Ekonomik İşbirliği Örgütü. Ş. Çalış, B. Akgün ve Ö. Kutlu (Ed.), Uluslararası örgütler ve Türkiye (s. 639-669). Çizgi Kitabevi.

Arı, T. (2013). Uluslararası ilişkiler ve dış politika, MKM Yayıncılık.

Aslan, N. (2005). Dünya Ekonomisinde Gelişmeler: Küreselleşme. O. Küçükahmetoğlu, H. Çeştepe ve Ş. Tüylüoğlu (Ed.), Ekonomik entegrasyon küresel ve bölgesel yaklaşım (s. 5-22). Ekin Yayıncılık.

Aşık, A. (2010). Karadeniz Bölgesi'ndeki değişimin analizi. Güvenlik Stratejileri Dergisi, 6(12), 33-57.

Baharçiçek, A. (2020). Yeni dünya düzeninde Türk dış politikası. Orion Kitabevi.

Bakan, S. (2019). İktisadi düşünceler ve devlet. Bilsam Yayınları.

Bakan, S. ve Tuncel, G. (2012). Küreselleşmenin ulus devlet üzerindeki etkisi. Birey ve Toplum, 2(3), 51-65.

Bensidoun, I. and Chevallier, A. (1997). Avrupa Birliği - Akdeniz Bölgesi ilişkileri ve serbest ticaret alanı oluşumu. T. Ünal (Çev.) İstanbul Ticaret Odasi.

BSEC. (2020). Organization of the Black Sea Economic Cooperation: http://www.bsec-organization.org/areas-of-cooperation (02.10.2020).

Çağıran, M. (2000). Karadeniz ekonomik işbirliği örgütü -hukuki yapısı ve gelişimi üzerine bir inceleme-. Galatasaray Üniversitesi Dergi Özel Sayl, $1-49$.

Çakır, A. (2001). Avrupa bütünleşmesinin siyasal kuramları. Beta Yayıncılık.

Çelik, K. (2005). Karadeniz Ekonomik İşbirliği. O. Küçükahmetoğlu, H. Çeştepe ve Ş. Tüylüoğlu (Ed.), Ekonomik Entegrasyon Küresel ve Bölgesel Yaklaşım (s. 439-448). Ekin Yayıncılık. 
S.Bakan-M.E. Güven Karadeniz Ekonomik İsbirliği Örgütü (KEİ)...

Çeşmecioğlu, S. (2003). Avrupa-Akdeniz ortakliğı ve Türkiye. İstanbul Ticaret Odas1.

Duran, M. (2004). Karadeniz ekonomik işbirliği ülkeleri arasında ticaretin gelişememesinin nedenleri ve çözüm önerileri. İstanbul Ticaret Odası.

Engin, B. (2016), Uluslararası ekonomik entegrasyonlar ve kuruluşlar. Ekin Yayıncilık.

Erkmenoğlu, F. (2001). Karadeniz Ekonomik İşbirliği (KEİ) - Örgütün Dünü, Bugünü ve Geleceği. Türkiye Cumhuriyeti Dışişleri Bakanlığl Yayınları, Uluslarararast Ekonomik Sorunlar Dergisi, (2), http://www.mfa.gov.tr/karadeniz-ekonomik-isbirlici-_kei_---orgutunundunu_-bugunu-ve-gelececi.tr.mfa (10.10.2020).

Ertürk, E. (1993). Ekonomik entegrasyon teorisi ve Türkiye'nin içinde bulunduğu entegrasyonlar, Ezgi Kitabevi Yayınları.

Gündüz, Z. (2012). Avrupa-Akdeniz ortaklığı: iyi niyetler, alışveriş listeleri ve alakart menüler üzerine. B. Coşkun ve B. Demirtaş (Ed.), Avrupa Birliği ve Komşuları Fırsatlar ve Zorluklar (s. 151-170). Elips Kitap.

Hepaktan, E. ve Çınar, S. (2011). Küreselleşmenin ekonomik entegrasyon üzerine etkileri. International Conference on Eurasian Economies, 69-77.

Heywood, A. (2014) Küresel siyaset. N. Uslu ve H. Özdemir (Çev.), Adres Yayınları.

Kahraman, S. (2008). AB-Akdeniz bölgesel politikaları ve Türkiye'nin uyumu. Journal of Yaşar University, 3(12), 1731-1742.

Kamalov, İ. (2009). Karadeniz bölgesindeki bazı güncel sorunlar. Karadeniz Araştırmaları, 6(21), 13-21.

Karagül, M. (2014). Uluslararası iktisadi örgütler ve azgelişmiş ülkeler, Nobel Yayıncilik.

Karakaş, Y. (2002). Avrupa Birliği'nde siyasal entegrasyon. Siyasal Kitabevi.

Karluk, R. (1995). Küreselleşen dünyada uluslararası ekonomik kuruluşlar ve entegrasyonlar. Anadolu Üniversitesi Basımevi.

Karluk, R. (2014). Avrupa Birliği kuruluşu, gelişmesi, genişlemesi, kurumları. Beta Yayıncilik. 
Kurtbağ, Ö. (2003). Avrupa-Akdeniz ortaklığı: Barselona süreci. Ankara Avrupa Çalışmaları Dergisi, 3(1), 73-92.

Özer, Y. (2005). Dünya ekonomisinde gelişmeler: bölgeselleşme. O. Küçükahmetoğlu, H. Çeştepe ve Ş. Tüylüoğlu (Ed.), Ekonomik Entegrasyon Küresel ve Bölgesel Yaklaşım (s. 23-41). Ekin Yayıncılık.

Özgöker, U. ve Batı, G. (2017). Uluslararası siyasi, askeri, ekonomik ve sosyo kültürel örgütler. Der Yayınları.

Özlem, K. (2017). Kosova Sorunu Ekseninde Küresel Aktörlerin Politikalarının Analizi. A. Sandıklı ve E. İsmayıl (Ed.), Küresel Riskler ve Bölgesel Krizler (s. 99-124). Bilgesam Yayınları.

Sanalan, T. (1997). Gümrük BIRLİĞI Karadeniz Ekonomik Isşbirliği bölgesi ve Doğu Karadeniz ekonomisi: Karadeniz Ekonomik Işsirliği (KEI). Türkiye Ekonomi Kurumu.

Şanlı, B. (2008). Ekonomik entegrasyon teorisi çerçevesinde Avrasya Birliği'nin olabilirliği. İstanbul Üniversitesi İktisadi ve İdari Bilimler Dergisi, 22(1), 13-30.

Şengül, C. (2009). Karadeniz Ekonomik İşbirliği ve birliğin Türkiye üzerindeki beklenen etkileri. (Yayımlanmamış Yüksek Lisans Tezi). Marmara Üniversitesi Sosyal Bilimler Enstitüsü.

Tezcan, E. (2016). Fransa-Avrupa Birliği İlişkileri. E. Tezcan ve İ. Aras (Ed.), Avrupa Birliği ve Üye Devletler AB15 Üzerine Bir Inceleme (s. 7-70). Detay Yayıncilik.

Tınar, M. (1998). Avrupa Birliği'nin Akdeniz politikası ve türkiye, Friedrich Ebert Stiftung.

T.C. Dışişleri Bakanlağı (2020). Karadeniz Ekonomik İşbirliği Örgütü (KEI): www.mfa.gov.tr/karadeniz-ekonomik-isbirligi-orgutu_kei_tr.mfa (20.09.2020).

T.C. Dişişleri Bakanlığı (2020a). Akdeniz Iç̧in Birlik (AIBB): http://www.mfa.gov.tr/akdeniz-icin-birlik.tr.mfa (05.10.2020).

TUIKK (2020). Türkiye İstatistik Kurumu Verileri. Türkiye İstatistik Kurumu: http://www.tuik.gov.tr/UstMenu.do?metod=temelist (01.10.2020).

Williams, A. (1996). Türkiye: Akdeniz bağlamı. C. Balkır and A. Williams (Ed.), Türkiye ve Avrupa İlişkileri (s. 65-91). İstanbul: Sarmal Yayınevi. 
S.Bakan-M.E. Güven Karadeniz Ekonomik İsbirliği Örgütü (KEİ)...

Yalçınkaya, A. (2017). Geçmişten günümüze Karadeniz Ekonomik İşbirliği örgütü. Marmara Üniversitesi Siyasal Bilimler Dergisi, (5), 1-16.

Yıldız, D. (2009). Doğu Akdeniz'de ısınan sular. Bizim Kitaplar. 